\title{
Arsenic intoxication: general aspects and chelating agents
}

\author{
Geir Bjørklund ${ }^{1} \cdot$ Petro Oliinyk ${ }^{2} \cdot$ Roman Lysiuk $^{2,3} \cdot$ Md. Shiblur Rahaman $^{4} \cdot$ Halyna Antonyak $^{5} \cdot$ Iryna Lozynska $^{2,3}$. \\ Larysa Lenchyk $^{6,7} \cdot$ Massimiliano Peana ${ }^{8}$
}

Received: 24 January 2020 / Accepted: 6 April 2020 / Published online: 9 May 2020

(c) Springer-Verlag GmbH Germany, part of Springer Nature 2020

\begin{abstract}
Arsenic (As) is widely used in the modern industry, especially in the production of pesticides, herbicides, wood preservatives, and semiconductors. The sources of As such as contaminated water, air, soil, but also food, can cause serious human diseases. The complex mechanism of As toxicity in the human body is associated with the generation of free radicals and the induction of oxidative damage in the cell. One effective strategy in reducing the toxic effects of As is the usage of chelating agents, which provide the formation of inert chelator-metal complexes with their further excretion from the body. This review discusses different aspects of the use of metal chelators, alone or in combination, in the treatment of As poisoning. Consideration is given to the therapeutic effect of thiol chelators such as meso-2,3-dimercaptosuccinic acid, sodium 2,3-dimercapto-1-propanesulfonate, 2,3-dimercaptopropanol, penicillamine, ethylenediaminetetraacetic acid, and other recent agents against As toxicity. The review also considers the possible role of flavonoids, trace elements, and herbal drugs as promising natural chelating and detoxifying agents.
\end{abstract}

Keywords Arsenic · Poisoning · Chelation therapy $\cdot$ Thiol chelators · Antioxidants $\cdot$ Herbal drugs $\cdot$ Nephroprotection · Flavonoids

\section{Abbreviations}

As Arsenic

BAL 2,3-Dimercaptopropanol (British Antilewisite, Dimercaprol)

Geir Bjørklund

bjorklund@conem.org

Massimiliano Peana

peana@uniss.it

1 Council for Nutritional and Environmental Medicine (CONEM), Toften 24, 8610 Mo i Rana, Norway

2 Danylo Halytsky Lviv National Medical University, Lviv, Ukraine

3 CONEM Ukraine Life Science Research Group, Danylo Halytsky Lviv National Medical University, Lviv, Ukraine

4 Graduate School of Environmental Science, Hokkaido University, Sapporo, Japan

5 Ivan Franko National University of Lviv, Lviv, Ukraine

6 National University of Pharmacy, Kharkiv, Ukraine

7 CONEM Ukraine Pharmacognosy and Natural Product Chemistry Research Group, National University of Pharmacy, Kharkiv, Ukraine

8 Department of Chemistry and Pharmacy, University of Sassari, Via Vienna 2, 07100 Sassari, Italy
DMPS

DMSA

EDTA

EMA

GSH

GSSG

IARC

$\mathrm{LD}_{50}$

MiADMSA

MnDMSA

MchDMSA

NAC

NBMI

NIOSH

ROS

SOD

US FDA

USGS

WHO
Sodium 2,3-dimercapto-1-propanesulfonate (unithiol)

Dimercaptosuccinic acid, (Succimer)

Ethylenediaminetetraacetic acid

European Medical Agency

Glutathione

Glutathione disulfide

International Agency for Research on

Cancer

Median lethal dose

Monoisoamyl 2, 3-dimercaptosuccinic acid

Monomethyl DMSA

Monocyclohexyl DMSA

$N$-Acetylcysteine

$N, N^{\prime}$-Bis-(2-mercaptoethyl) isophthalamide

National Institute for Occupational Safety

and Health

Reactive oxygen species

Superoxide dismutase

United States Food and Drug

Administration

United States Geological Survey

World Health Organization 


\section{Introduction}

Arsenic (As) is a metalloid element (atomic weight $74.9216 \mathrm{amu}$, atomic number 33, group 15 of the periodic system). As in trace amounts is an essential nutrient for energy generation in prokaryotes and several eukaryotes, including birds and mammals. It is also possible that As is an essential trace element for humans, although its role in metabolism has not been clearly defined (Oremland and Stolz 2003; Uthus 1992; Zoroddu et al. 2019). The human body contains approximately $0.08-0.02 \mathrm{mg} \mathrm{As} / \mathrm{kg}$, which mainly is concentrated in liver, kidneys, lungs, bones, and hair. The environmental presence of As imposes a major health problem worldwide since it has been clearly shown that excessive or prolonged exposure to its compounds results in severe acute or chronic toxicity leading to a range of medical complications termed as "Arsenicosis" (Abdul et al. 2015; McCarty et al. 2011; Straif et al. 2009).

Arsenic commonly occurs naturally in two oxidation states, $\mathrm{As}(\mathrm{III})$ and $\mathrm{As}(\mathrm{V})$, and rarely in the 0 or -3 state.

Both As(III) and As(V) compounds cause acute and chronic adverse health effects. Trivalent arsenicals have more potent toxicological properties than pentavalent arsenicals (Ratnaike 2003). In mice, the $\mathrm{LD}_{50}$ for oral intake of arsenic trioxide is $26 \mathrm{mg} / \mathrm{kg}$ (Hughes 2002). When As reacts with metals, arsenides are formed. With halogens, As results in the formation of halides. With halogens, As results in the formation of halides. As salts are soluble in water, resulting in its easy release from the earth's crust into water due to the natural processes of geogenic leaching of rocks and sediments containing this element.

Moreover, anthropogenic geothermal energy extraction and mining activities, as well as excess pumping of shallow groundwater, increase As dissipation in the environment (Masuda 2018). Since the number of people who are at risk of chronic As poisoning for a long-term intake of contaminated water and food is extremely high, the development of specific therapies is required. There are two main approaches to minimize the human health impact of As poisoning and As-contaminated groundwater: prevention and cure. However, there is no particular therapy for chronic As exposure that is more frequently caused by the long-term ingestion of contaminated water and food. Many factors can affect the bio-accessibility, metabolism, and toxicity of As, such as chelation mechanisms, diet, and nutrition. Measures are urgently required to focus on reduction in As toxicity, early diagnosis, and therapy of As-induced outcomes. Treatment options advocated are chelation therapy, vitamin and mineral supplements, and antioxidant therapy (Nurchi et al. 2020; Ratnaike 2003).

In the present review, after the description of the multiple causes of As exposure and the related clinical features, a particular focus is given on updated knowledge of the treatments/interventions on As poisoning through chelation therapy, natural dietary supplementation, nutritional interventions. Moreover, we provide indications to decrease the disease impact through counseling and proper nutritional education.

\section{Routes of arsenic exposure}

\section{Environmental and anthropogenic causes}

Large environmental amounts of As are coming both from natural and anthropogenic sources, the latter being predominant due to extensive metal mining and smelting activities (Ravenscroft et al. 2011).

Arsenic is the 53rd most abundant element and is widely distributed in the earth's crust in many minerals, often together with other metals in sulfide ores as MAsS or MAs (Mandal and Suzuki 2002; Smedley and Kinniburgh 2002). Although the content of As in the earth's crust is only $0.0005 \%$, this element is part of more than 200 different mineral forms. The main mineral hosts of As are sulfides, as arsenopyrite (FeAsS), orpiment $\left(\mathrm{As}_{2} \mathrm{~S}_{3}\right)$, and realgar $\left(\mathrm{As}_{4} \mathrm{~S}_{4}\right)$ (Garelick et al. 2008). FeAsS, with $46 \%$ As content, is the leading industrial mineral (Wang and Mulligan 2006). As is also widely distributed in nature in the form of arsenite $\left(\mathrm{As}_{2} \mathrm{O}_{3}\right)$ and arsenate $\left(\mathrm{As}_{2} \mathrm{O}_{5}\right)$. Small As concentrations are often associated with lead $(\mathrm{Pb})$, copper $(\mathrm{Cu})$, and silver $(\mathrm{Ag})$ ores. When the minerals are smelted, gaseous As is trapped and transformed in arsenic trioxide $\left(\mathrm{As}_{2} \mathrm{O}_{3}\right)$. Thus, $\mathrm{As}_{2} \mathrm{O}_{3}$ is mainly obtained as a by-product of the smelting of $\mathrm{Cu}, \mathrm{Pb}$, or gold ( $\mathrm{Au})$ ores, from which the most commercially available As compounds are obtained (Pinto and McGill 1953). In China, the Philippines and Peru, As has been recovered from orpiment and realgar, in Chile from copper-gold ores, whereas it is associated with Au occurrences in Canada and cobalt arsenide in Morocco. In 2018, the average annual global production of As was approximately estimated in 35,000 metric tons, with China $(24,000)$, Morocco (6000), Namibia (1900), and Russia (1500) as the world leaders in $\mathrm{As}_{2} \mathrm{O}_{3}$ production (USGS 2019). In the past decades, As production increased by $25 \%$ every 10 years. Consequently, the technogenic pollution by As compounds related to metal processing and burning brown coal poses a critical threat (Garelick et al. 2008).

All around the world, mining-related As contamination of soils, sediments, surface waters, and groundwater has been reported (Costagliola et al. 2008; Gao et al. 2019; GarciaSanchez et al. 2010; Garelick et al. 2008; Ravenscroft et al. 2011). Moreover, As is used in alloys mainly in association with $\mathrm{Pb}$ or $\mathrm{Cu}$ in semiconductors, pigment, glass, car batteries, and enamels. In developing countries, As compounds 
are widely utilized in agriculture as herbicides, pesticides, and insecticides as sodium arsenate, calcium arsenate, cacodylic acid, and other compounds. Therefore, the use of Ascontaining chemicals in agriculture transfers this toxic metal into food of both animal and vegetable origin (Han et al. 2003; Upadhyay et al. 2019). Millions of people worldwide are significantly exposed to high As levels contained in meat, fish, grains, and vegetables, health supplement products (herbal-based medicines), as well as through food that has been processed using As contaminated water. Foodborne As exposure causes a significant global burden of human disease (Oberoi et al. 2014). The organoarsenic compounds roxarsone (4-hydroxy-3-nitrobenzenearsonic acid), nitarsone (4-nitrophenyl)arsonic acid), arsanilic acid (4-aminophenylarsonic acid), and carbarsone ([4-(carbamoylamino)phenyl] arsonic acid) are still widely used as feed additives in poultry and swine production as antiparasitics and weight gainers (Nachman et al. 2013, 2017; Zhao et al. 2020). Several As compounds are used as preservatives for wood (arsenate of $\mathrm{Cu}$ and chromium), cotton desiccants (arsenic acid), ammunition, and in some pharmaceuticals.

Moreover, tobacco smokers can be exposed to concentrations of inorganic As from tobacco plants that have been cultivated in As rich soil or treated with lead arsenate insecticide. Furthermore, As alone or in the co-exposition with other known or suspected carcinogens results in very high risks of lung or bladder cancer (Ferreccio et al. 2013). The widespread use of As compounds has caused and still leads to numerous chronic and acute poisonings, and for this reason, As is listed as one of ten chemical elements posing significant threats to the global public health (Quansah et al. 2015; WHO 2004).

Arsenic-contaminated aquifers are estimated to affect 300 million people in more than one-third of the countries worldwide (Hassan 2018). Normally, As concentration in natural water is lower than $10 \mu \mathrm{g} / \mathrm{l}$, which is the standard safety limit recommended by WHO. Water frequently contains less than $1 \mu \mathrm{g} \mathrm{As} / 1$, although some areas of the world have higher levels than $5000 \mu \mathrm{g}$ As/l. Regions with high As groundwater levels are found in the United States, Argentina, Chile, Mexico, China, Hungary, India, Taiwan, Bangladesh, and Vietnam (Naujokas et al. 2013; Smedley and Kinniburgh 2002). Countries such as India and Bangladesh admit, in the absence of an alternative water source, the limit of $50 \mu \mathrm{g}$ As/l.

\section{Use of arsenic in medicine}

It is well established that As is a traditional poison responsible for various human diseases, including cancer as well as deleterious effects on the urinary bladder, lung, kidney, and skin. Beyond these effects, As-based preparations have been shown to possess beneficial therapeutic properties. The medical use of As has been known since at least 4000 years ago, and even today, some As compounds are administered and used in several countries. Historically, arsenic trioxide has been applied in traditional ancient Chinese medicine and later in western medicine. In the middle of the nineteenth century, As-based preparations were the first effective chemotherapy agents against syphilis, parasites, and leukemia (Au 2011). Since 1845, Fowler's solution, which contains $1 \%$ potassium arsenite $\left(\mathrm{KAsO}_{2}\right)$, has been used to treat leukemia, chronic bronchial asthma, malaria, and psoriasis (Ho and Lowenstein 2016). Until the late 1950s, its use continued in the US for the treatment of syphilis, malaria, and other diseases (Jolliffe 1993). Preparations also based on organic As compounds have also found clinical application due to their positive therapeutic effects. For instance, arsenobenzene has been administered to treat protozoal infections. Arsphenamine (salvarsan, 4,4',4"'-(1,2,3-Triarsirantriyl)tris(2-aminophenol)) has been used to treat syphilis. A significant disadvantage of the As-drugs is related to their high toxicity, as the induction of severe side effects already mentioned (Cooper et al. 2007; Liu et al. 2020). Nowadays, chronic and fatal acute As poisoning from traditional Chinese medicine use is still a threat (Chang et al. 2018; Wu et al. 2013; Zheng et al. 2019). In a clinical case of a Chinese man suffering from fatigue, weakness, numbness, together with hyperkeratosis in his hands and feet, the inorganic As level in urine was more than 120 times higher $(1235 \mu \mathrm{g} / \mathrm{l})$ than normal. The patient reported consuming for 5 years homemade traditional "herbal balls" containing up to 80 ingredients, comprising As (Spilchuk and Thompson 2019). The homeopathic drug "Arsenicum album 30C", for which a scientific debate continues particularly in India about its effectiveness in treating different disease states [as in ameliorating the health condition from chronic As poisoning (Mallick et al. 2003)], is currently advertised in the preventive and prophylactic treatment against the dangerous and contagious epidemic coronavirus COVID-19. Such a drug is made by sequential centesimal dilution of arsenic trioxide mother solution for thirty times until there is not a trace of As in solution or even a single water molecule that has encountered any of the original As atoms. Scientists globally consider homeopathy as a scientifically failed medical practice (Ernst 2002) and reject that "Arsenicum album 30C" can act against the new virus. Furthermore, these claims can be counterproductive in dealing with a serious health emergency, and they can lead to potentially dangerous consequences, i.e., cases of acute As poisoning for those people who might think of preparing homemade As-based drugs without proper dilution.

Nevertheless, the current interest in the application of As-based drugs as therapeutic remedies in medicine is particularly flourishing and precisely focused in the cancer research area (Alipour et al. 2019; Wahiduzzaman et al. 
2020). In 2001, US FDA and in 2002 EU commission approved an arsenic trioxide drug for its high effectiveness in the treatment of acute and promyelocytic leukemia (Au 2011; Chen et al. 2011; Iland and Seymour 2013; Liu et al. 2012). Recently $\mathrm{As}_{2} \mathrm{O}_{3}$ has also been proposed as a promising candidate for lung cancer treatment, alone or in combination with the classic cisplatin drug (Huang and Zeng 2019; Medici et al. 2015; Miodragović et al. 2019; Yang et al. 2019). The synergic effect of $\mathrm{As}_{2} \mathrm{O}_{3}$ with a B cell lymphoma-2 (Bcl-2) family inhibitor (ABT-737) in uterine cervical cancer cells was also evidenced to ameliorate ABT-737 target therapy (Hsin et al. 2019). Recently, a controlled-release of $\mathrm{As}_{2} \mathrm{O}_{3}$ by multifunctional nanoparticles strategy (nano- $\mathrm{ZrO}_{2}$ carriers with mitochondrial targeting) in order to improve the treatment of hepatocellular carcinoma and reduce the toxic side effects, has been investigated with positive results (Wu et al. 2020). Arsenene nanosheets have been proposed as biosafe new therapeutic agents for acute promyelocytic leukemia cells (Wang et al. 2019). Arsenic sulfide $\left(\mathrm{As}_{4} \mathrm{~S}_{4}\right)$ has been suggested as a potential antitumor agent for gastric cancer since it effectively inhibits human gastric adenocarcinoma cell line proliferation by inducing apoptosis both in vitro and in vivo through a p53-dependent pathway (Zhang et al. 2015). Mild or moderate side effects are common (10-30\%), but severe and sometimes fatal complications can occur when As exceeding toxicity thresholds. Therefore, the administration of these drugs should be evaluated when beneficial effects outweigh metal toxicity. The development of new strategies employing the use of As-based drugs in coated NPs systems provides a promising alternative for safe and effective tumor treatment (Lian et al. 2019). However, consideration of the individual genetic predisposition, co-exposure to other toxins, diet, and particularly vulnerable neurological conditions should be taken carefully into account in prescribing these treatments (Bjørklund et al. 2020).

\section{Arsenic in chemical weapons}

From World War I and particularly during World War II started the era of the use of chemical poisoning weapons, including toxic As compounds. Figure 1 reports the list of the most used As-based blister or vesicant, vomiting, and blood agents used as chemical weapons to date (Hoenig 2007). These very last warfare agents affect the body by being absorbed into the blood with the routes of inhalation or ingestion. All these As-based agents possess the characteristics of high toxicity, rapidity of action after environmental distribution, and long persistence (Li et al. 2016).

The most famous poisonous substance, 2-chlorovinyldichloroarsine (Fig. 1), known with the common names of Lewisite (Germany), L (USA), and P-43A (Russia), is a colorless liquid with an irritating geranium odor acting as a powerful blister agent and lung irritant. The boiling point of Lewisite is $+190{ }^{\circ} \mathrm{C}$, which allows it to be classified as a persistent toxic substance. The freezing point is $-45^{\circ} \mathrm{C}$, meaning that there are no climatic restrictions on its use in different seasons of the year. In summer, its poisonous properties remain on the ground for 4-12 h, while in winter, several days. The volatility at $20^{\circ} \mathrm{C}$ is $4.5 \mathrm{~g} / \mathrm{m}^{3}$, and since the vapor is heavier than air, it will settle in low-lying areas. Lewisite causes damage both in the drip-liquid state and in the form of steam or fog. Following contact and aerosol exposure, its toxic properties occur in the skin, lungs, and eyes, while in the case of penetration into the gastrointestinal tract, abdominal pain, nausea, vomiting, diarrhea, and anorexia occur. The skin-resorptive $\mathrm{LD}_{50}$ for humans is $20 \mathrm{mg} / \mathrm{kg}$. By absorption through the skin, Lewisite causes general intoxication of the body. The most sensitive organs to the action of vapors are the eyes and upper respiratory tract. The threshold concentration causing eye irritation is $0.002 \mathrm{mg} / \mathrm{l}$. Severe eye irritation and damage to the upper respiratory tract occurs after $15 \mathrm{~min}$ at a Lewisite concentration of $0.01-0.03 \mathrm{mg} / \mathrm{l}$. The relative toxicity of Lewisite during inhalation LC $\tau 50$ is $1.3 \mathrm{mg} / \mathrm{l} / \mathrm{min}$ (Goldman and Dacre 1989; Hoenig 2007; NIOSH 2011; Dyadchenko et al. 2018).

In 1941, As pollution of the Black Sea waters was due to the flooding of containers of Lewisite and other warfare agents (sometimes mixed to alter their properties for military effectiveness). The Black Sea is the world's largest natural anoxic closed water basin with a very high degree of isolation, which causes persistent pollution from numerous sources. Economic activity such as fishing, collection of rapans and mussels, common sources of local food, is usually carried out also in the contaminated areas. Therefore, there is a severe risk to the health of the population living around these regions. The concentration of As in seawater of Kerch Strait (the strait connecting the Black Sea and the Sea of Azov) ranged from 4.58 to $132 \mathrm{mg} / \mathrm{l}$ in 2007, and from 0.21 to $6.27 \mathrm{mg} / \mathrm{l}$ in 2008 (Prokhach and Mykhalska 2009). In 2010, the deadline for the destruction of container shells expired, and toxic substances started leaking into the sea.

As of 7 June 2010, only 113 containers of yperite (sulfur mustard, 1-chloro-2-[(2-chloroethyl)sulfanyl]ethane) and Lewisite were deactivated of the 1200 flooded ones in 11 sites along the coast of the Crimean peninsula. Near the Swallow's Nest, where 24 barrels were flooded, some of the containers were destroyed; and due to their As content, the water exceeded the norm by more than 100 times (Samar 2013). Conversely, in a study devoted to the determination of toxic metals, including As, in selected Black Sea fish species in the Bulgarian region (sampling season 2010) gave encouraging results within acceptable limits for human consumption and decreased total metal concentration according to the analysis performed in the period 2004-2006 (Makedonski et al. 2017). 
Fig. 1 Arsenic-based warfare agents. Blister agents: Lewisite L-1 (2-Chlorovinyldichloroarsine), L-2 (Bis[(E)-2-chlorovinyl]arsinous chloride), L-3 (Tris[(E)-2-chlorovinyl] arsine), Methyldichloroarsine MD, Ethyldichloroarsine ED, Phenyldichloroarsine PD.

Vomit agents: Adamsite-DM (10-chloro-5,10-dihydrophenarsazine chloride), Diphenylchloroarsine DA, Diphenylcyanoarsine DC. Blood agents: Arsine-SA (arsenic trihydride)

\section{Blister Agents}
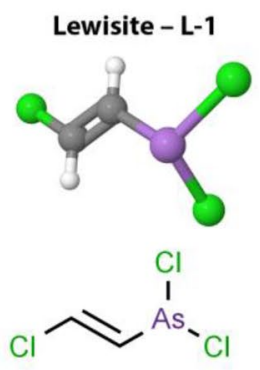

Methyldichloroarsine - MD<smiles>C[As](Cl)Cl</smiles>

Ethyldichloroarsine - ED<smiles>CC[As](Cl)Cl</smiles>

Phenyldichloroarsine - PD

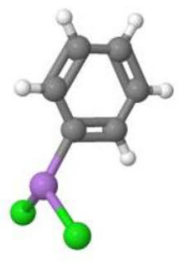<smiles>Cl[As](Cl)c1ccccc1</smiles>

\section{Vomit Agents}

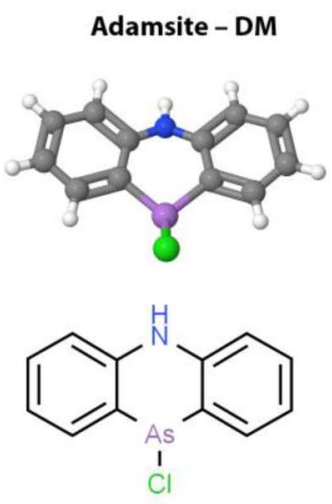

Diphenylchloroarsine - DA

Diphenylcyanoarsine - DC

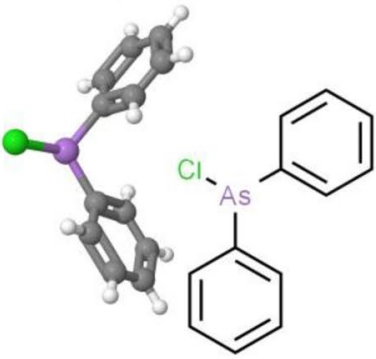<smiles>N#C[As](c1ccccc1)c1ccccc1</smiles>

\section{Blood Agents}

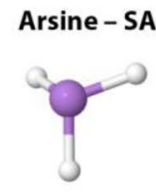

$\mathrm{AsH}_{3}$

Currently, chemical warfare agents are destroyed via chemical neutralization processes or high-temperature incineration. Before the international treaty "Convention on the Prevention of Marine Pollution by Dumping of Wastes and Other Matter", signed in 1972 in London by a majority of nations, millions of tons of munitions have been disposed throughout the world's oceans determining an environmental risk for its natural resources (Bełdowski et al. 2016; Czub et al. 2018; Edwards and Bełdowski 2016; Szubska 2018).
The current use of chemical weapons poses a serious threat to people from short to a long spread of As in the environment. Most states have joined the Chemical Weapons Convention (Convention on the Prohibition of the Development, Production, Stockpiling and Use of Chemical Weapons and on their Destruction), which obligates the destruction of all chemical weapons by 2012 (OPCW 1992). However, about 25 nations currently possess weapon stockpiles or are suspected of secretly stockpiling or possessing chemical 
weapons research programs. In Syria, for example, at least four plants for the production of toxic substances as weaponries have been counted. The access to weapon stockpiles by terrorists or accidental exposure could be highly dangerous for people and the environment. In July 2012, Syrian authorities officially recognized the availability of chemical weapons in the country, and according to the United Nations, their stocks reached thousands of tons before the Civil War. From 2013 to the end of 2016, chemical attacks took place in the suburbs of Damascus and in the Hama provinces (2014), in Idlib (2014 and 2015), Homs (2015) and Aleppo (2016).

\section{Clinical features of arsenic toxicity}

The toxic mechanism for As is explained by its ability to block sulfhydryl (-SH) groups in enzymes and other biologically active compounds and thus disrupt the biochemical processes of metabolism. In addition, As can replace iodine (I), selenium (Se), and phosphorus (P) (Hughes et al. 2011). As exhibits its toxicity by causing lipid peroxidation, inactivating up to 200 enzymes, especially those involved in cellular energy processes, as well as in DNA synthesis and reduction.

In acute As exposure, a metallic taste occurs in the mouth with a slight odor of garlic in the breath and dysphasia, followed by nausea, vomiting, burning in the stomach and esophagus, abdominal pain, and diarrhea. Moreover, cyanosis, hypoxic encephalopathy, convulsions, acute tubular necrosis, cardiovascular, and respiratory symptoms such as hypotension, pulmonary edema, and heart failure can occur. Death follows in the first few hours from shock or some days later from acute renal or liver failure (Fowler et al. 2015) (Fig. 2).

Prolonged As poisoning has a wide range of clinical features and leads to multisystemic diseases (Fig. 2). In a chronic As poisoning, the element accumulates in liver, kidneys, heart, and lungs, muscle tissues, nervous system, gastrointestinal tract, spleen, and other tissues containing keratin. After about 2 weeks since As ingestion, it starts to deposit in the hair and nails. The highest concentration of As is observed in the kidneys and liver (Fowler et al. 2015). Cases of encephalopathy and peripheral neuropathy have been reported (Berbel-Garcia et al. 2004). Because of biochemical transformations of the absorbed As, monomethylarsonic and dimethylarsinic acids are formed in the liver, which are less toxic. About $50 \%$ of the absorbed dose can be excreted in the urine in 3-5 days (Abernathy et al. 1999; Ratnaike 2003; Thompson 1993).

Arsenic causes myocardial injury, cardiac arrhythmias, and cardiomyopathy by reducing the activity of antioxidant enzymes of the heart, namely superoxide dismutase, catalase, glutathione $S$-transferase, glutathione reductase and glutathione peroxidase (Manna et al. 2008). Toxic polyneuropathy and peripheral neuropathy often occur. Tetraplegia or paresis develop with the prevalence of lesions of the peroneal muscles. In rare cases, there are injuries of the individual cranial nerves: facial, trigeminal, vagus, and

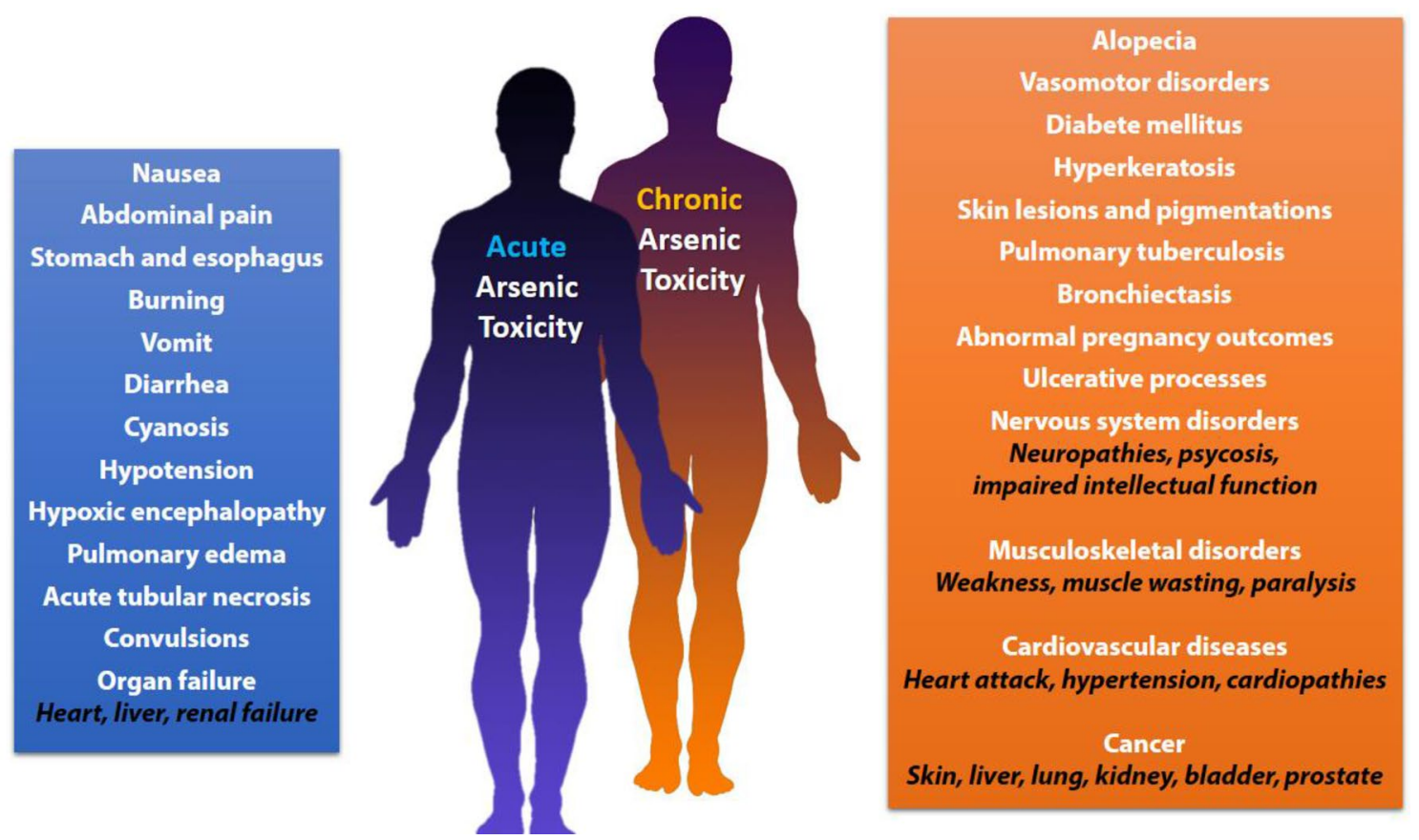

Fig. 2 Outcomes of acute and chronic arsenic exposure 
sublingual ones. Toxic polyneuropathy is usually accompanied by pronounced vegetative trophic disorders: hyperkeratosis, over-exfoliation of the skin on the extremities, hair loss, ulcerative processes on the gums, and vasomotor disorders. The development of clinical symptoms of toxic polyneuropathy initially occurs with symptoms of irritation of the nerve trunks. This leads to sharp pains in the extremities, accompanied by the phenomena of hyperpathia, ataxia, and a marked decrease in vibrational sensitivity. The progressive development of movement disorders, muscle weakness, and paresis can lead to complete paralysis. Behavioral changes, obfuscation, and memory loss are also observed. It has also been reported psychoses due to As poisoning (Fajzulina and Atamanjuk 2007; Jomova et al. 2011; Schenk and Stolk 1967; Wu et al. 2017). Epidemiological evidence indicated that low dose chronic exposure to As, especially in the form of arsenite, increases the risk of developing skin, kidney, bladder, liver, lung, and prostate cancer (Arita and Costa 2009; Benbrahim-Tallaa and Waalkes 2008). Since arsenite is weakly mutagenic, carcinogenesis may be mediated by epigenetic mechanisms, as in the case of other carcinogens (Chervona et al. 2012; Peana et al. 2013; Zoroddu et al. 2010).

Both inorganic and organic As compounds pass the human placenta in late pregnancy, where they accumulates as well as in the fetus. Existing studies on the effects of As in high doses indicate a risk for pregnancy, whereas the effects in small doses start to appear in the literature (Milton et al. 2017). As-containing compounds cause an abnormal pregnancy outcome in experimental animals at sufficiently high levels. Abnormal pregnancy outcomes, including miscarriages, stillbirths, and infant deaths have been reported in communities that consumed drinking water with As concentrations above $50 \mathrm{ppb}(\mu \mathrm{g} / \mathrm{l})$ and often above this level (Amadi et al. 2017; Concha et al. 1998; Rahman et al. 2019). Epidemiological studies of areas with high levels of As in drinking water indicate an association between in utero As exposure and the development of adult diseases such as cancer, chronic pulmonary disease, cardiovascular disease, and diabetes (Sanchez et al. 2016; Steinmaus et al. 2014; Vahter 2008; Young et al. 2018).

Urinary As concentration is used to quantify and monitor recent As poisoning. Analyses of blood, hair, and fingernails samples are also good indicators of exposure. Because of the short half-life of As in blood, hematological estimation is useful in particular in the diagnosis of acute intoxication. Inorganic As incorporates into hair and fingernails due to its affinity to the sulfhydryl groups in keratin. The metal deposition requires at least 2 weeks after exposition to appear. In chronic poisonings, As levels found in hair samples are in the range $0.1-0.5 \mathrm{mg} / \mathrm{kg}$, while in acute poisonings, the As concentrations reach values between 1.0 and $3.0 \mathrm{mg} /$ $\mathrm{kg}$. Another common clinical manifestation of chronic As exposure is the appearance of Mee's lines in the nails. Hair and nail tests are particularly useful to determine the level of As exposure in the previous 6-12 months (in these case, long hair are needed to define the history associated with exposure). Other key characteristic features as skin lesions, melanosis, keratosis, and pigmentation are often used for diagnosing chronic As poisoning since they usually develop from 5 to 10 years after initial exposure. Analytical methods used to measure As levels are based on anodic stripping voltammetry (ASV), atomic absorption spectroscopy (AAS), radiochemical methods, X-ray spectroscopy, highperformance liquid chromatography-atomic fluorescence spectrometry (HPLC-AFS), inductively coupled plasmaoptical emission spectroscopy (ICP-OES), inductively coupled plasma-mass spectrometry (ICP-MS), or graphite furnace atomic absorption spectrometry (GFAAS) (Caussy 2006; Keil et al. 2011; WHO 2001).

\section{Fundamental principles for application of chelation therapy and major arsenic chelating agents}

The employment of chelation mechanisms in the treatment of arsenical intoxication began during World War II, with the synthesis of British Anti-Lewisite antidote (BAL). Chelation therapy is considered as an efficient and well-known primary treatment for As poisoning as well as other toxic metals (Gerhardsson and Kazantzis 2015; Kazantzis 2007; Nurchi et al. 2019). Chelation is a chemical event in which what is called a ligand binds metal atom/ion via a coordination bond in a cyclic or ring-like structure. A ligand is an ion or neutral molecule that has two or more donor atoms capable of donating a pair of electrons and forming a covalent bond with the metal ion. Good chelating agents form chemically inert and non-toxic metal complexes. Chelating agents should rapidly and easily be excreted from the body by glomerular filtration, and about $50 \%$ appears in the urine within $1 \mathrm{~h}$ without any further interaction with the vital organs (Gerhardsson and Kazantzis 2015). They can also enter the cell membrane to remove intracellular toxic metals. A good chelating agent can compete with endogenous ligands and must have a relatively higher affinity and selectivity for toxic metals than for the desired and essential body metals, whose homeostasis must not be disturbed (Aaseth et al. 2016b; Crisponi et al. 2015; Kim et al. 2019).

Nonetheless, chelation can lead to the removal of not only toxic metals but also the essential ones, or cause a redistribution of toxic metals into other tissues or organs, such as the brain (Aaseth et al. 2016a; Lachowicz et al. 2018). Chelators are routinely used in the treatment of the overload of essential elements, such as in the case of transfusional siderosis in thalassemic patients, and also in some other 
hemoglobinopathies (Nurchi et al. 2016). Some chelators may also have toxic effects or exert severe side effects per se (Crisponi et al. 2015; Kazantzis 2007). Chelation therapy for As toxicity is thought to be the specific therapy for the relief of systemic clinical manifestations and reduction of As stores in the body, which subsequently reduces several severe outcomes and cancer risk. Chelation prohibits As from interacting with biological targets like proteins and DNA and facilitates its removal from the body (Flora et al. 2007; Kosnett 2013).

One of the mechanisms involved in the pathogenesis of As-mediated toxicity is associated with its high affinity to thiol groups in molecules, Cysteine-rich motifs on proteins, and enzymes such as metallochaperones and zinc fingers (Pfaff et al. 2019; Shen et al. 2013; Shi et al. 2004). Monomethylarsenite strongly inhibits pyruvate dehydrogenase $(\mathrm{PDH})$ and $\alpha$-ketoglutarate dehydrogenase (KGDH) complex, whereas inorganic arsenite exerts a more significant effect to PDH. This has been attributed to the affinity of the metalloid to the proximal 1,3 sulfhydryl groups of the lipoic acid, cofactor of PDH and KGDH, whose inhibition has a deleterious effect on cellular respiration due to the indirect and direct roles of these enzymes in the citric acid cycle (Bergquist et al. 2009). Based upon thiol affinity, exposure to arsenite also decreases the cellular concentration of reduced glutathione (GSH) and results in cellular redox imbalance
(Jomova et al. 2011; Rubino 2015). It was reported that $\mathrm{N}$-acetylcysteine (NAC) (Fig. 3) as a thiol-containing antioxidant decreased As-mediated oxidative damage and NAC reduction of As poisoning may be carried out thanks to the improvement of the GSH/GSSG ratio and through chelation in U937 monocytes and macrophages (Ghani et al. 2014; Rossignol 2019).

During arsenite stress in Saccharomyces cerevisiae, two key residues in histone proteins $\mathrm{H} 3$ and $\mathrm{H} 4$ have been identified which are important for the regulation of $\operatorname{Hog} 1$ (Mitogen-activated protein kinase) signaling, Fps1 activity (aquaglyceroporin), and ACR3 (arsenical resistance-3 family) expression (Thakre et al. 2020). These are H3K4 and H4K16, both targets of methylation and acetylation processes, whose disruption has been involved in gene dysregulation and cancer genesis (Zoroddu et al. 2010).

Chelating agents commonly used against As poisoning are specifically thiol chelators like 2,3-dimercaptopropanol, meso-2,3-dimercaptosuccinic acid, and its derivatives sodium 2,3-dimercapto-1-propanesulfonate (DMPS, unithiol), and 3-Mercapto-D-valine (Penicillamine, PCA) (Fig. 3) (Aaseth et al. 2016a; Flora et al. 2007).

The right choice of a chelator (alone or in combination) suitable for As treatment and its proper dosage is of great significance in order to obtain the desired result and minimize the side effects. For acute As poisoning, the
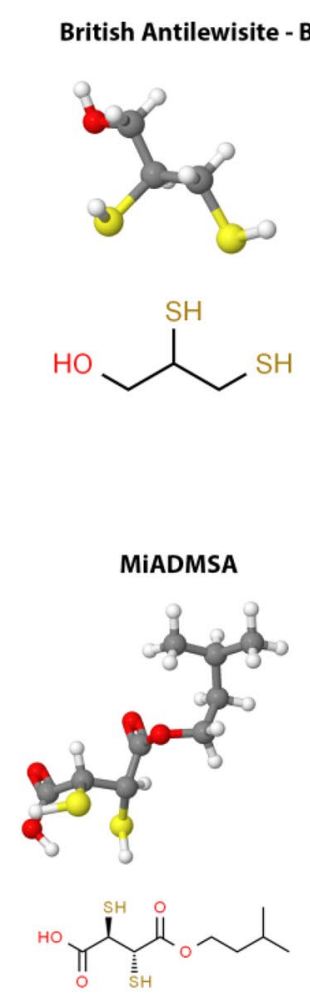
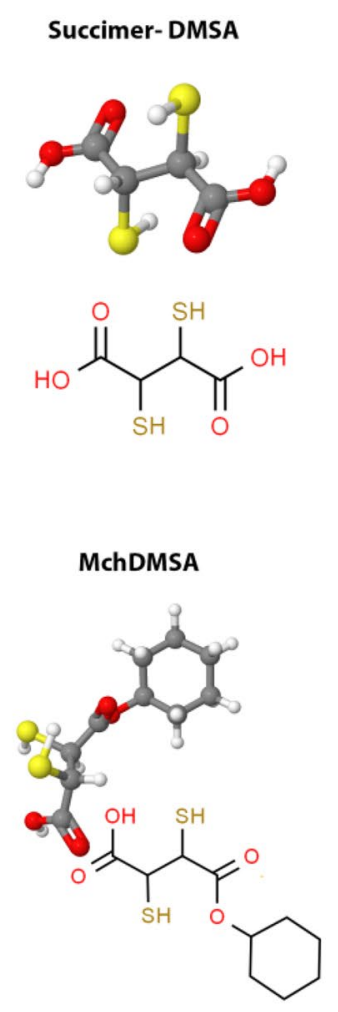
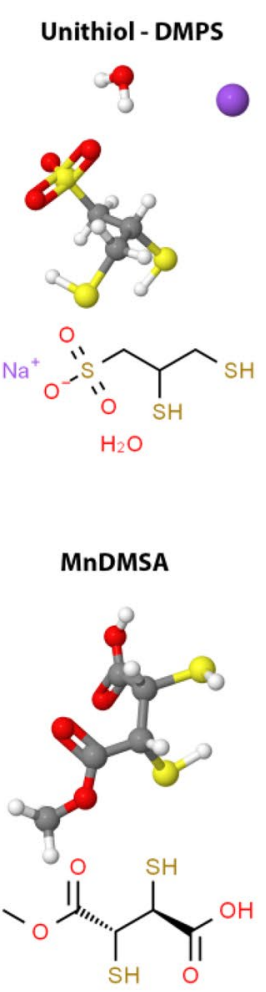
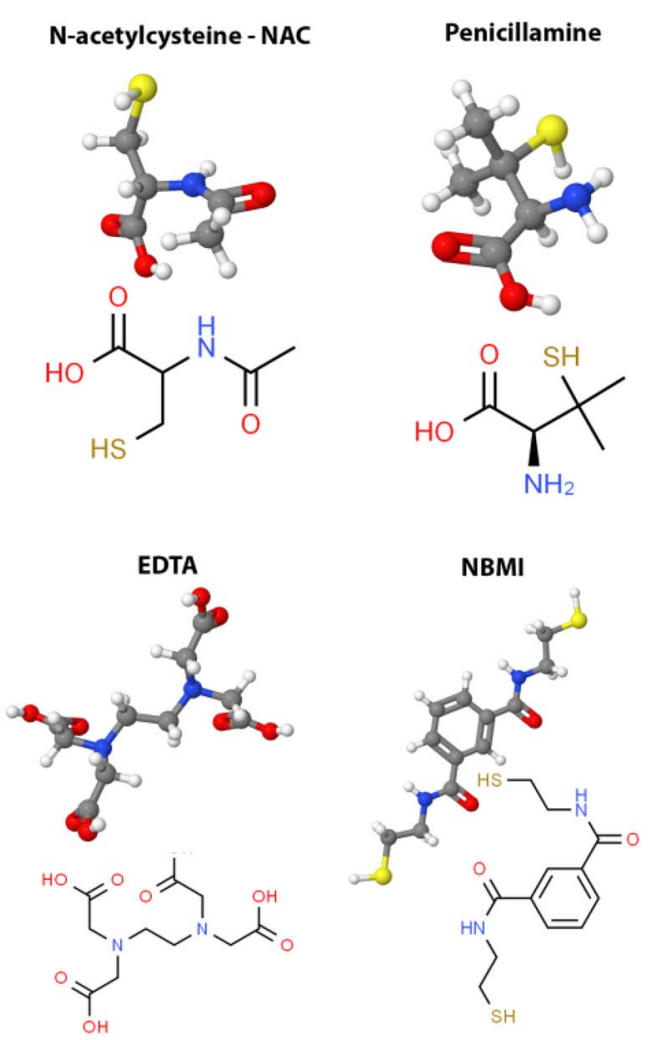

Fig. 3 Chelating agents used in arsenic poisoning 
aforementioned chelating agents have been applied, whereas effective treatment of chronic As toxicity has not been established yet, though some studies showed satisfactory results in response to the use of DMPS.

\section{BAL}

British Anti-Lewisite (BAL) (2,3-dimercaptopropanol) (Fig. 3) was synthesized as a specific antagonist to the vesicant arsenical war gas Lewisite during World War II. It is used as a chelator in chronic As poisoning where the signs of arsenicosis are severe, or the patient has complications (Mathieu et al. 1992). Currently, the clinical use of this drug is restricted for acute As intoxications to only the initial treatment, because of its toxicity and the necessity of frequent painful parenteral administrations (Nurchi et al. 2020). BAL is formulated in peanut oil because of its lipophilic nature and administered intramuscularly at an initial dose of $3-5 \mathrm{mg} / \mathrm{kg}$ of body weight every $4 \mathrm{~h}$. This chelating agent demonstrated high systemic distribution and ability to compete effectively with the thiol groups of proteins for binding the $\mathrm{As}$ ion (as well as $\mathrm{Au}, \mathrm{Hg}$, and $\mathrm{Pb}$ ), which is then excreted in the urine. This therapy is frequently effective in preventing or neutralizing systemic toxicity, but severe side effects occur. These include hypertension, nephrotoxicity, and the propensity to concentrate As in several organs, including brain and testes (Yadav and Flora 2016).

In most cases, the degree of recovery from neuropathy, aplastic anemia, encephalopathy, and jaundice is limited and directly related to the initial severity of the systemic involvement and the rapidity with which chelation therapy is initiated. When symptoms such as melanosis and keratosis, appear on the skin, BAL, as well the other chelating agents as penicillamine, DMSA and DMPS, support melanosis clearance together with mechanical scraping with the help of urea in cream or Vaseline, followed by 6-10\% salicylic acid, for smoothening of skin (Saha 1995). Symptomatic treatment with antibiotics should be implemented when internal complications occur as organ dysfunctions or histological, histochemical abnormalities (Saha et al. 1999). The development of safer agents has rendered BAL almost obsolete except for sporadic cases (Gerhardsson and Aaseth 2016).

\section{DMSA and its derivatives}

DMSA is an effective antidote to many toxic metals and metalloids, including As, and is well-tolerated with relatively rare adverse effects (Bjørklund 2015; Bradberry and Vale 2009; Chang et al. 1996; Dart et al. 1994; Maiorino et al. 1989). DMSA is generally administered orally at $8-50 \mathrm{mg} /$ $\mathrm{kg}$ /day therapy doses (Chang et al. 1996). DMSA hydrophilicity limits its access to intracellular compartments and is consequently distributed mostly in the extracellular fluid
(Bradberry and Vale 2009). It has limited bioavailability and is mostly found covalently bound to plasma proteins with a half-life in humans lower than $4 \mathrm{~h}$ (Dart et al. 1994). Of an orally administered dose of DMSA, 10 to $25 \%$ is excreted in the urine, the majority within $24 \mathrm{~h}$ (Maiorino et al. 1989; Sears 2013). The remainder is primarily eliminated in the feces (Chang et al. 1996; Sears 2013). In a randomized placebo-controlled trial involving 22 patients, DMSA was not effective in the development of any clinical or biochemical benefit or histopathological improvement of skin lesions in patients with chronic arsenicosis (Guha Mazumder et al. 1998). DMSA, as well as BAL, causes $\mathrm{Zn}$ and $\mathrm{Cu}$ depletion. Some sporadic adverse effects ( $4 \%$ of the patients) are related to skin lesions as papular and herpetic rashes, mucocutaneous eruptions, and pruritus.

A list of DMSA derivatives, manifesting least toxicity and exhibiting better permeability across cell membranes, have also been developed and are currently in different phases of clinical and pre-clinical trials. These include monoisoamyl DMSA (MiDMSA), monocyclohexyl DMSA (MchDMSA), and monomethyl DMSA (MmDMSA) (Fig. 3).

MiDMSA is a derivative that retains a high As affinity through its sulphydryl groups and does not redistribute it, as DMSA, to other organs. The lipophilic nature of MiDMSA enables it to chelate both extracellular and intracellular toxic metal ions, which aids in the removal of As from the cytosol and organelles (Aaseth et al. 2015; Pachauri et al. 2013). The concomitant use of DMSA with these long carbon chain analog, as MiDMSA or MchDMSA, showed an improved efficiency in reducing As levels and alleviating oxidative stress when compared to DMSA alone (Bhadauria and Flora 2007; Kosnett 2013; Mishra et al. 2008; Modi and Flora 2007). Nowadays, one of the strategies in the treatment of As poisoning is also the co-administration of antioxidants (Flora and Pachauri 2010). It has been observed that the combined administration of NAC with MiADMSA was more effective than MiADMSA monotherapy against chronic As poisoning in guinea pigs (Kannan and Flora 2006).

\section{DMPS}

DMPS, whose synthesis was first reported in 1956, is capable of forming complexes with a number of metals and metalloids and has been used and proven effective in the treatment of heavy metal poisonings but the efficacy for treating acute As poisoning is limited (Aposhian et al. 1997; Kalia and Flora 2005). DMPS is not able to cross the blood-brain barrier, contrary to BAL. Consequently, it does not redistribute As to the brain (Gerhardsson and Aaseth 2016; Jones 1995). The excretion of DMPS and its metabolites is relatively fast. Within 5-6 h, about $80 \%$ is excreted in the urine (Bjørklund 2015). The oral absorption of DMPS is significantly higher than DMSA (Sears 2013). Other 
administrations are through intravenous, rectal, and transdermal routes. In acute As poisoning, intravenously administration of NAC demonstrated better therapeutic efficacy than intramuscular DMPS (Martin et al. 1990). After intravenous injection of DMPS, the half-life in plasma is $30-45 \mathrm{~min}$, and its metabolites are rapidly eliminated from the body through the kidneys within $2 \mathrm{~h}$ (Aposhian et al. 1986).

Some adverse effects during treatment with DMPS include gastrointestinal problems, skin reactions, mild neutropenia, and elevated liver enzymes. As BAL and DMSA, also DMPS enhance $\mathrm{Cu}$ and $\mathrm{Zn}$ urinary excretion, which in some patients give deficiency symptoms (Flora and Pachauri 2010; Kosnett 2004). The trace elements $\mathrm{Cu}$ and $\mathrm{Zn}$ are both antagonists in function and essential for living cells (Bjørklund 2013; Chasapis et al. 2012; Zoroddu et al. 2019). Consequently, monitoring their concentrations during chelation treatment is required (Lachowicz et al. 2015). In particular, DMPS influences the mineral equilibrium of the body more than DMSA and is more toxic (Aposhian et al. 1989). Therefore DMSA should be preferred to DMPS (Kazantzis 2007). However, for the treatment of As poisoning in patients with anuria, DMPS is probably the safest and most effective chelating agent, while DMSA should not be used (Hsiao et al. 2019).

\section{PCA}

D-Penicillamine (3-Mercapto-D-valine, PCA) (Fig. 3) is an amino acid that contains an additional SH group and belongs to the class of stable non-physiological amino acids; it is a structural component of the penicillin molecule from which is obtained by hydrolysis. PCA is capable of forming nontoxic, water-soluble chelated compounds with heavy metals, which are then excreted in the urine. Due to the presence of a stable sulfhydryl group, PCA can decompose the disulfide bonds of macromolecular complexes. Historically, PCA was the first chelator used for Wilson's disease because of its affinity for $\mathrm{Cu}$ (Walshe 1956). It also mobilizes As, but it is not generally a drug of choice (Hall 2002). In the clinical case of poisoning with As, which developed after the administration of contaminated Ayurvedic drugs, the state of patients was improved after the withdrawal of the medications and treatment with PCA (Pinto et al. 2014). Although, in this case, the patient's condition was improved, the effectiveness of PCA for treating As poisoning is contradictory. It has been reported that in animal experiments, the effectiveness of PCA with respect to As toxicity has not been confirmed (Aposhian et al. 1981; Hilmy et al. 1991; Kreppel et al. 1989).

The great advantage of this drug is that it may be orally administered and is well absorbed from the gastrointestinal tract. The peak of plasma concentration is observed 1-4 h after oral intake. PCA has, however, a high frequency of side effects, although this is a minor problem when the body contains large As amounts. Side effects of PCA administration include fever, lymphadenopathy, neutropenia, thrombocytopenia, proteinuria anorexia, nausea, joint pain, allergic reactions, and other phenomena that occur quite rarely (e.g., peripheral neuropathy, exfoliative dermatitis, polymyositis, dermatomyositis, and alopecia) (Friedman 1977; Kreppel et al. 1989; Schardein and Macina 2006).

\section{EDTA}

The well-known chelating agent EDTA (ethylenediaminetetraacetic acid) (Fig. 3) has been widely used in medicine, but there is categorically no role for EDTA in As poisoning. The chemical and biological activity exhibited by EDTA is affected by the formation of four or six bonds with its oxygen donors with transition or alkaline metal ions (in particular $\mathrm{Ca}, \mathrm{Fe}, \mathrm{Mn}, \mathrm{Cu}, \mathrm{Zn}, \mathrm{Hg}, \mathrm{Pb}$ ). The impact of EDTA treatment of disorders associated with pentavalent As poisoning is caused by the effect on paracellular transport. The removal of extracellular $\mathrm{Ca}^{2+}$ causes retraction of the tightjunctional proteins with the formation of large paracellular openings between cells, which leads to a functional increase in permeability of the intestinal epithelium and further removal of arsenical species in Caco-2 cell line as a model (Calatayud et al. 2010). Several side effects are associated with the administration of EDTA including hepatotoxicity, renal failures, respiratory and gastrointestinal symptoms, arrhythmias, tetany, hypocalcemia, hypotension, mucocutaneous lesions, bone marrow depression, convulsions, fatigue, headache, fever, nasal congestion, lacrimation, glycosuria, myalgia, and increased urinary frequency. Moreover, prolonged chelation treatment with EDTA fallouts in the depletion of essential metals as $\mathrm{Zn}, \mathrm{Cu}$, and manganese $(\mathrm{Mn})$. One of the negative features of using EDTA in the treatment of chronic As intoxication is its ability to inhibit $\delta$-aminolevulinic acid dehydratase by the removal of $\mathrm{Zn}$ from the site and further development of degenerative cellular processes via oxidative stress (Modi and Flora 2007).

\section{NBMI}

Recently, NBMI ( $N, N^{\prime}$-bis-(2-mercaptoethyl) isophthalamide, Emeramide) has been proposed as an alternative to the current chelators (Fig. 3). NBMI has been shown to possess the capacity to penetrate cell membranes and to cross BBB combined with an antioxidant property for scavenging and reducing the toxicity levels of hydroxyl free radicals, dangerous for the normal redox status of the cells. NBMI was first proposed against $\mathrm{Hg}$ poisoning but also appears to be, at least in vitro, able to selectively chelate As ions as well as other toxic and non-essential metals such as $\mathrm{Pb}$, cadmium $(\mathrm{Cd})$, and uranium $(\mathrm{U})$ without evidence of 
toxicity (Schutzmeier et al. 2018). NBMI is based on carboxyl benzoate with two arms made of cysteamine moieties attached to the 1st and 3rd carbon groups of the aromatic ring. The two-SH groups of cysteamines are free to flex and rotate in order to accommodate several toxic soft acid metal ions. Trial phase 1 safety study and phase 2 clinical trials showed no adverse effects in humans (Trial identifier: NCT04183595, Emera008). Currently, NBMI is going through the FDA and the European Medical Agency (EMA) and the drug approval process.

\section{Chelation therapy for arsenic poisoning: a practical approach}

Acute As intoxication can occur from the accidental intake of pesticide or insecticide, as the result of medical use of Asbased drugs or from intentional poisoning during homicidal purposes as in terroristic attacks or suicide attempts.

In acute As poisoning, metallic taste and dry mouth appear, with difficulty and pain in swallowing. In any way, gastrointestinal disorders occur like colic, nausea, vomiting, which can become irresistible, diarrhea, stool in the form of rice broth with an admixture of blood. The loss of fluids leads to severe dehydration of the body. An increased weakness, headache, dizziness, and decreased body temperature and blood pressure as a result of vascular collapse appear. The occurrence of periorbital edema, visual disturbances, skeletal muscle cramps, oliguria, proteinuria, hematuria is possible. After $8-15$ days from the onset of the disease, there is a sharp pain in the extremities, trophic disorders, paresthesia, paresis, with predominant extensor lesions. Death comes from paralysis of the respiratory and vascular centers. In the survivors, there is a severe diffused lesion of the nervous system in the form of toxic encephalopathy (impaired speech, coordination of movements, epileptiform convulsions, hyperkinesia by type of chorea, memory impairment, psychosis), encephalomyelopolyneuritis (Wexler 2000; Ratnaike 2003). In the treatment of acute As poisoning, it is first of all necessary to prevent or minimize its absorption from the gastrointestinal tract; to provide general supportive therapy to aid with breathing, blood circulation, and water-electrolyte balance, and to control the state of the nervous system. The removal of absorbed As may be facilitated by diuresis, bile excretion, hemodialysis, or exchange transfusion (Kazantzis 2007). Arsenic is slowly bound to serum protein ranging from $5.3 \%$ (trivalent inorganic As) to $6.5 \%$ (pentavalent inorganic As) (Zhang et al. 1998), but has a high volume of distribution (from 3.3 up to $4 \mathrm{l} / \mathrm{kg}$ ) and rapidly passes from serum to tissues (its half-life in phase I occurs within 1-2 h, where about $90 \%$ As redistributes within 3 h) (Lai et al. 2005).
Theoretically, there is a therapeutic window in the first few hours after ingestion for early extracorporeal purification of blood without chelation. Nevertheless, the chelator is strongly recommended for all stages of acute As poisoning in patients with anuria, as it always increases the availability of metal in the serum for dialysis (Mathieu et al. 1992) and minimizes the likelihood of further morbidity and mortality. The current recommended treatment for acute As poisoning is the use of specific metal chelators, able to interact with As and to form strong lowtoxic complex compounds that are mainly excreted in the urine. Chelation therapy for acute As poisoning is recommended because the benefits exceed the risk of side effects. Even when there are unconfirmed suspicions of As ingestion, the administration of chelating agents is recommended for the prevention of acute renal failure. Thiol-based metal chelators such as DMSA, DMPS, BAL, and PCA are mainly administered in acute As poisoning (Bjørklund 2015; Modi and Flora 2007; Vasken Aposhian et al. 1984). DMPS and DMSA, due to their high water solubility, low toxicity, and high therapeutic indexes, are superior to BAL in the treatment of acute As poisoning and DMPS should be selected as the first choice respect DMSA in both oral and/or parenteral chelation treatment because of its greater antidotal potency (Aaseth et al. 2016a; Kosnett 2013). In acute As poisoning, DMPS is used as a 5\% solution for intravenous and intramuscular injection, as well as tablets and capsules for oral administration. The drug is scarcely toxic: $\mathrm{LD}_{50}$ for mice after subcutaneous administration is $5.22 \mathrm{mM} / \mathrm{kg}$ (Aposhian et al. 1981). DMPS is well-tolerated, but in some cases of prolonged use, nausea, tachycardia, and allergic reactions may occur. All these effects quickly disappear when the drug is discontinued (Karp and Danova 1997). After $5 \mathrm{~h}$ since intravenous administration of DMPS, only $0.9 \%$ has been found free, $36.6 \%$ is associated with non-protein species. In contrast, the highest amount (62.5\%) is found bonded to plasma proteins by a disulfide bond, in particular albumin (84\%) and higher molecular weight proteins or aggregates (16\%) (Maiorino et al. 1996). It has been suggested that these protein- and non-proteinDMPS species may prolong the chelation activity toward toxic metal ions, representing a reservoir of DMPS, which can be released by disulfide reduction in vivo. In tissues, the maximum concentration of DMPS is detected in the kidneys, the minimum in the brain. It is mainly found in the extracellular fluid, poorly permeating through cell membranes. DMPS is an effective antidote for many inorganic and organic As compounds, including arsenites, arsenates, arylarsenoxides, acetarsolum, etc. (Aposhian et al. 1981; Karp and Danova 1997). DMPS has been shown to reduce the half-life of As from liver tissues by 2.1 times, from whole blood by 12 times, and plasma 1.6 
times. The effectiveness of treatment of acute and chronic toxic metal poisoning with one chelating agent is in many cases insufficient, so a number of authors have proposed multi-component poisoning therapy, the advantage of which is the possibility of using several drugs together in lower doses (it leads to the enhancement of overall effectiveness of the combined treatment). For example, when EDTA together with DMPS was given to mice after $1 \mathrm{~h}$ since cadmium chloride administration, $100 \%$ survival has been observed (Schubert and Derr 1978). The combination of DMSA and MiADMSA, respect to mono-therapy (DMSA alone), has been found to enhance As removal from hepatic tissue and prevent hepatic apoptosis, reducing oxidative stress efficiently, giving lower As concentrations in blood and soft tissues (Mishra et al. 2008). In a recent study, the use of ascorbic acid (vita$\min$ C) and DMSA was evaluated successfully in rats coexposed to As and fluoride contaminated water. The combination therapy showed reduced As and F burden and oxidative stress (Mittal et al. 2018). The protocols for the treatment of acute poisoning, approved by the Ministry of Health of Ukraine, recommend an internal administration of penicillamine in cases of As poisoning, combining it with Pyridoxine hydrochloride $(1 ; 2.5 ; 5 \%$ solution), followed by gastric lavage (Vlasyk et al. 2009). The beneficial role of the combined chelation therapy with the commonly used iron $(\mathrm{Fe})$ chelators deferasirox and deferiprone was also estimated for As poisoning showing its effectiveness in depleting As concentration from soft tissues in rats (Amiri and Mirhoseiny 2017; Nurchi et al. 2016). Chelation treatment appears a promising therapeutic measure as regards alleviation of symptoms for severe cases of chronic As poisonings (Gerhardsson and Aaseth 2016). In particular, in a study performed with a group of patients suffering from chronic As toxicity due to long term consumption of As-contaminated water demonstrated the efficacy of DMPS with a substantial improvement of neuropathy and lung symptoms respect to the group treated with placebo (Guha Mazumder et al.
2001), whereas DMSA has been found to be unsuccessful (Guha Mazumder et al. 1998).

\section{Natural products as promising chelating and detoxifying agents for chronic arsenic poisoning}

The application of natural chemical chelators is one of the traditional methods of removing toxic metals from the body (Bhattacharya 2017). Natural antioxidants found in a correct diet as flavonoids, lipoic acid, carotenoids, vitamin $\mathrm{C}$ and $\mathrm{E}$, taurine, gallic acid, curcumin, minerals, amino acids, etc. have shown beneficial effects in counteracting metal toxicity by increasing methylation capacity and free ROS scavenging. Medicinal plants currently attract the scientific interest as potential remedies in case of toxic metal poisoning due to their lesser adverse effects (Mehrandish et al. 2019), since their health benefits for humans are caused by the totality of secondary metabolites, including important antioxidant molecules flavonoids, accompanied by various macroelements and trace elements (Konieczynski et al. 2018) (Table 1). Flavonoids possess a number of properties ranging from in vitro antioxidant and anti-inflammatory effects, ROS scavengers activity, to chelation ability for metal ions (Cherrak et al. 2016; Chirumbolo et al. 2018; Fang et al. 2002; Korkina and Afanas'ev 1997). These polyphenols induce phase II detoxifying enzymes (e.g., glutathione $S$-transferase) and CYP (Cytochromes P450)-mediated detoxification, which is of significant impact on the inactivation of toxicants (Chirumbolo et al. 2018; Valko et al. 2006). A report on As-induced toxicity in Swiss albino mice treated with naringenin showed significant amelioration in the hematological and serum biochemical profiles and normalization of the hepatic and renal functions (Mershiba et al. 2013; Roy et al. 2014). Other examples include taurine, quercetin, silymarin, rutin, and the mixed polyphenolic flavonoids present in green tea leaves in exerting a protective action against As-caused damage

Table 1 Therapeutic strategy for mono- or combined therapy in arsenic toxicity

\begin{tabular}{ll}
\hline Chelating agents for acute As toxicity & $\begin{array}{c}\text { DMPS, DMSA, MiADMSA, MmDMSA, MchDMSA, BAL, EDTA, penicillamine alone or in combina- } \\
\text { tion }\end{array}$ \\
$\begin{array}{l}\text { Nutrients from diet or supplements } \\
\text { Medicinal plants/herbal extracts }\end{array}$ & $\begin{array}{c}\text { Allium sativum, Azadirachta indica, Camellia sinensis, Crataegi fructus, Curcuma longa, Hyperici } \\
\text { herba, Moringa oleifera, Nigella Sativa, Spirulina, Tiliae flores, etc. }\end{array}$ \\
Antioxidants & $\begin{array}{c}\text { Flavonoids (naringenin, quercetin, silymarin, rutin, catechins); carotenoids ( } \beta \text {-carotene, lutein), } \alpha \text {-lipoic } \\
\text { acid }\end{array}$ \\
Micronutrients & Se, Zn, Ca, Mg \\
Vitamins & A (retinoic acid), C (ascorbic acid), E (a-tocopherol), M (folic acid) \\
Protein/amino acids & Methionine, taurine, $N$-acetylcysteine \\
\hline
\end{tabular}

${ }^{a}$ Some with both antioxidant and chelation properties 
through their antioxidant and chelating ability (Das et al. 2009; Sarkozi et al. 2015; Sharma and Flora 2018).

Besides of secondary plant metabolites flavonoids, herbal drugs, e.g., Hyperici herba, Tiliae flores, and Crataegi fructus, are also important sources of essential elements. Some significant correlations have been determined between the totality of flavonoids and Fe, $\mathrm{Zn}$, and Mn content in the analyzed phytopharmaceuticals (Konieczynski et al. 2018). Total antioxidant capacity depends upon the activities of three enzymes: manganese superoxide dismutase (MnSOD), glutathione peroxidase-1 (GPx1), and catalase, which contribute to the removal of ROS since they are involved in a common detoxification pathway (Bastaki et al. 2006). The GPx1 enzyme functions as a homotetramer with Se and GSH as the cofactors, able to enzymatically reduce hydrogen and lipid peroxides, and result in the formation of oxidized glutathione (GSSG) (Bastaki et al. 2006; Brown et al. 2000; Lubos et al. 2011).

The protective effect of antioxidant trace elements upon simultaneous exposure with toxic metals has been shown on various cell cultures (Binte Hossain et al. 2018). Human selenoproteins protect the cells from damages caused by cellular protein oxidation (Steinbrenner et al. 2016; Zoidis et al. 2018). Selenium counteracts and reduces the toxicity of heavy metals such as $\mathrm{Hg}, \mathrm{Cd}, \mathrm{Pb}$, and hexavalent chromium in the body (Antonyak et al. 2008, 2018). The relieving action of Se against As toxicity, both in vitro and in vivo has also been investigated. Defense from oxidative injury due to As treatment has been demonstrated as a detoxification pathway by Se supplementation through the selenoproteins upregulation (GPx and thioredoxin reductase) (Rahman et al. 2019). The combination of As and Se enhanced antioxidant defense in As-treated PC12 cells, positively regulating autophagy and apoptosis (Rahman et al. 2018). Seleniumenriched diet caused higher fecal and urinary As excretion and reduction of its residues in kidneys with simultaneous improvement of the GSH levels and health indices in Astreated rats (Sah et al. 2013).

Currently, drug-induced nephrotoxicity is an important concern since the administration of nephrotoxic medicines is unavoidable in modern clinical practice (Kim and Moon 2012). Oxidative stress also contributes to the development of chronic renal disease, as unbalanced lipid peroxidation leads to endothelial dysfunction and loss of plasma SOD and GPx activity and Se levels (Dennis and Witting 2017). Arsenic, interacting with substances consisting of sulphydryl groups, restrains the GSH reductase and produces immoderate ROS in renal tissue (Ghabaee et al. 2017). GSH is involved in detoxification of ROS and xenobiotics via glutathione $S$-transferase conjugation (Dennis and Witting 2017; Ghabaee et al. 2017). Besides of detoxifying enzymes, processes of ROS scavenging also comprise signaling pathway Nrf2/Keap1/ARE. Some medicines of plant origin are known to be activators of the Nfr2 action (Bjørklund et al. 2018). Treatment with $\mathrm{Zn}$ during gestation and lactation developed a protective effect in As-induced $(5 \mathrm{mg} / \mathrm{kg} /$ day as sodium meta-arsenite) oxidative stress in rats' renal tissue, which was confirmed by the improvement of the malondialdehyde (MDA) and GSH levels, also as the histopathological changes (Bhardwaj and Dhawan 2019). Zinc improved renal antioxidant status in rats in the models of cyclosporine- and mercuric chloride-induced kidney damage (Ghabaee et al. 2017). The hepatoprotective effect of $\mathrm{Zn}$ alleviates chronic As poisoning also in aquatic species (Zhao et al. 2019).

The ameliorative effect of several plants and herbal extracts has been attributed to their antioxidant properties (Oyagbemi et al. 2018; Sharma and Flora 2018; Susan et al. 2019). Several research studies demonstrate the perspectives for application in the treatment of heavy metals poisoning of the following herbal drugs: garlic, milk thistle, cilantro, ginkgo, turmeric, phytochelatins, triphala, some herbal fibers, and green algae (Bhattacharya 2017). Among them, Azadirachta indica (plant, Neem), Nigella Sativa (plant, black cumin), Allium sativum (plant, garlic) and Spirulina (algae) were evaluated in several clinical studies as remedies for As-induced keratosis in humans and were also successful as bioremediators in As exposed aquatic organisms or in reducing As-polluted wastewater (Roy et al. 2017; Sayed et al. 2019). Garlic, onion, leek, and chive, due to their content in organosulfur substances, contribute to detoxification of heavy metals such as $\mathrm{Pb}$ and As carried out by the liver (Mehrandish et al. 2019). Curcumin can reduce liver toxicity caused by heavy metals due to its significant antioxidant capacity and chelating ability (Mehrandish et al. 2019). Curcumin-encapsulated chitosan nanoparticles (nano-curcumin) showed to combat As toxicity at a much lower dose compared to free curcumin (Yadav et al. 2012). Recently, synergistic therapeutic effects against As-generated oxidative stress were evidenced by the combinatorial drug delivery strategy employing nano-curcumin and nano-MiADMSA in rats (Kushwaha et al. 2018).

\section{Concluding remarks}

Arsenic and its compounds are used in technology and agriculture as pesticides, herbicides, and insecticides in many countries of the world. All this leads to environmental pollution, accumulation of As in groundwater, as well as the contamination of medicinal plants, agricultural products, and food. Cases of accidental or non-accidental poisoning of people by various mineral or organic compounds of As are not infrequent. Chelation therapy is used to treat different types of poisoning. A number of chelating agents are available, in particular, for the treatment of acute arsenicosis, whereas there is still no safe and effective antidote available 
for treating chronic As intoxication. The above discussion provides an insight into the therapeutic role of classical and new promising chelators in As-induced toxicity. Although there are a variety of chelating agents that have been tested in the treatment of As poisoning, their effectiveness is strongly related to the general health condition of the patient, mode of administration, dose, and resistance to biotransformation. Several strategies occur for the treatment of As poisoning, including monotherapy or a combination of structurally different chelating agents as well as co-administration of natural and synthetic antioxidants. Nano-drug delivery is currently evaluated as a promising future alternative to conventional chelators for its efficacy and safety. Nutritional factors play a critical role in antagonizing free radical species and increasing As methylation. The influence of a correct daily diet and/or the use of nutrient supplements (vitamins, micronutrients, proteins, etc.) helps to reduce the damages caused by arsenicosis and protect from chronic exposure, especially for peoples living in contaminated regions.

Funding This research did not receive any specific grant from funding agencies in the public, commercial, or not-for-profit sectors.

\section{Compliance with ethical standards}

Conflict of interest The authors declare they have no actual or potential competing financial interests.

\section{References}

Aaseth J, Crisponi G, Anderson O (2016a) Chelation therapy in the treatment of metal intoxication. Academic Press, Cambridge

Aaseth J, Gerhardsson L, Skaug MA, Alexander J (2016b) Chapter 1general chemistry of metal toxicity and basis for metal complexation. In: Aaseth J, Crisponi G, Andersen O (eds) Chelation therapy in the treatment of metal intoxication. Academic Press, Boston, pp 1-33

Aaseth J, Skaug MA, Cao Y, Andersen O (2015) Chelation in metal intoxication-principles and paradigms. J Trace Elem Med Biol 31:260-266. https://doi.org/10.1016/j.jtemb.2014.10.001

Abdul KS, Jayasinghe SS, Chandana EP, Jayasumana C, De Silva PM (2015) Arsenic and human health effects: a review. Environ Toxicol Pharmacol 40(3):828-846. https://doi.org/10.1016/j. etap.2015.09.016

Abernathy CO, Liu YP, Longfellow D et al (1999) Arsenic: health effects, mechanisms of actions, and research issues. Environ Health Perspect 107(7):593-597. https://doi.org/10.1289/ ehp. 99107593

Alipour F, Riyahi N, Safaroghli-Azar A, Sari S, Zandi Z, Bashash D (2019) Inhibition of PI3K pathway using BKM120 intensified the chemo-sensitivity of breast cancer cells to arsenic trioxide (ATO). Int J Biochem Cell Biol 116:105615. https://doi. org/10.1016/j.biocel.2019.105615

Amadi CN, Igweze ZN, Orisakwe OE (2017) Heavy metals in miscarriages and stillbirths in developing nations. Middle East Fertil Soc J 22(2):91-100. https://doi.org/10.1016/j.mefs.2017.03.003
Amiri A, Mirhoseiny Z (2017) Beneficial role of deferasirox and deferiprone in the mobilization of arsenic and recovery of iron in rat tissues. Main Group Chem 16(1):1-5

Antonyak H, Iskra R, Panas N, Lysiuk R (2018) Selenium. In: Malavolta $\mathrm{M}$, Mocchegiani $\mathrm{E}$ (eds) Trace elements and minerals in health and longevity. Springer, Berlin, pp 63-98

Antonyak H, Panas N, Zhylishchych Y, Biletska L, Skab O (2008) Hematological effects of heavy metals and selenium in animals. Annales UMCS Pharmacia 21:259-262

Aposhian HV, Arroyo A, Cebrian ME et al (1997) DMPS-arsenic challenge test. I: increased urinary excretion of monomethylarsonic acid in humans given dimercaptopropane sulfonate. J Pharmacol Exp Ther 282(1):192-200

Aposhian HV, Maiorino RM, Dart RC, Perry DF (1989) Urinary excretion of meso-2,3-dimercaptosuccinic acid in human subjects. Clin Pharmacol Ther 45(5):520-526. https://doi.org/10.1038/ clpt. 1989.67

Aposhian HV, Maiorino RM, Weber GL, Aposhian MM, McKelvie DH, Wilson SE (1986) Water soluble dithiol metal binding agents-efficacies and biotransformation. Acta Pharmacol Toxicol (Copenh) 59(Suppl 7):467-470. https://doi. org/10.1111/j.1600-0773.1986.tb02804.x

Aposhian HV, Tadlock CH, Moon TE (1981) Protection of mice against lethal effects of sodium arsenite-a quantitative comparison of a number of chelating agents. Toxicol Appl Pharmacol 61(3):385392. https://doi.org/10.1016/0041-008x(81)90360-4

Arita A, Costa M (2009) Epigenetics in metal carcinogenesis: nickel, arsenic, chromium and cadmium. Metallomics 1(3):222-228. https://doi.org/10.1039/b903049b

Au WY (2011) A biography of arsenic and medicine in Hong Kong and China. Hong Kong Med J 17(6):507-513

Bastaki M, Huen K, Manzanillo P et al (2006) Genotype-activity relationship for Mn-superoxide dismutase, glutathione peroxidase 1 and catalase in humans. Pharmacogenet Genom 16(4):279-286. https://doi.org/10.1097/01.fpc.0000199498.08725.9c

Bełdowski J, Szubska M, Emelyanov E et al (2016) Arsenic concentrations in Baltic Sea sediments close to chemical munitions dumpsites. Deep Sea Res Part II 128:114-122. https://doi. org/10.1016/j.dsr2.2015.03.001

Benbrahim-Tallaa L, Waalkes MP (2008) Inorganic arsenic and human prostate cancer. Environ Health Perspect 116(2):158-164. https ://doi.org/10.1289/ehp.10423

Berbel-Garcia A, Gonzalez-Aguirre JM, Botia-Paniagua E et al (2004) Acute polyneuropathy and encephalopathy caused by arsenic poisoning. Rev Neurol 38(10):928-930

Bergquist ER, Fischer RJ, Sugden KD, Martin BD (2009) Inhibition by methylated organo-arsenicals of the respiratory 2-oxo-acid dehydrogenases. J Organomet Chem 694(6):973-980. https://doi. org/10.1016/j.jorganchem.2008.12.028

Bhadauria S, Flora SJ (2007) Response of arsenic-induced oxidative stress, DNA damage, and metal imbalance to combined administration of DMSA and monoisoamyl-DMSA during chronic arsenic poisoning in rats. Cell Biol Toxicol 23(2):91-104. https ://doi.org/10.1007/s10565-006-0135-8

Bhardwaj P, Dhawan DK (2019) Zinc treatment modulates hematological and morphological changes in rat erythrocytes following arsenic exposure. Toxicol Ind Health 35(9):593-603. https://doi. org/10.1177/0748233719878563

Bhattacharya S (2017) Medicinal plants and natural products in amelioration of arsenic toxicity: a short review. Pharm Biol 55(1):349354. https://doi.org/10.1080/13880209.2016.1235207

Binte Hossain KF, Rahman MM, Sikder MT, Saito T, Hosokawa T, Kurasaki M (2018) Inhibitory effects of selenium on cadmiuminduced cytotoxicity in PC12 cells via regulating oxidative stress and apoptosis. Food Chem Toxicol 114:180-189. https://doi. org/10.1016/j.fct.2018.02.034 
Bjørklund G (2013) The role of zinc and copper in autism spectrum disorders. Acta Neurobiol Exp (Wars) 73(2):225-236

Bjørklund G (2015) Clinical use of the metal chelators calcium disodium edetate, DMPS, and DMSA. Saudi J Kidney Dis Transpl 26(3):611-612. https://doi.org/10.4103/1319-2442.157416

Bjørklund G, Dadar M, Martins N et al (2018) Brief challenges on medicinal plants: an eye-opening look at ageing-related disorders. Basic Clin Pharmacol Toxicol 122(6):539-558. https://doi. org/10.1111/bcpt.12972

Bjørklund G, Tippairote T, Rahaman MS, Aaseth J (2020) Developmental toxicity of arsenic: a drift from the classical doseresponse relationship. Arch Toxicol 94(1):67-75. https://doi. org/10.1007/s00204-019-02628-x

Bradberry S, Vale A (2009) Dimercaptosuccinic acid (succimer; DMSA) in inorganic lead poisoning. Clin Toxicol (Phila) 47(7):617-631. https://doi.org/10.1080/15563650903174828

Brown K, Pickard K, Nicol F, Beckett G, Duthie G, Arthur J (2000) Effects of organic and inorganic selenium supplementation on selenoenzyme activity in blood lymphoctyes, granulocytes, platelets and erythrocytes. Clin Sci 98(5):593-599

Calatayud M, Gimeno J, Velez D, Devesa V, Montoro R (2010) Characterization of the intestinal absorption of arsenate, monomethylarsonic acid, and dimethylarsinic acid using the Caco-2 cell line. Chem Res Toxicol 23(3):547-556. https://doi.org/10.1021/tx900 $279 \mathrm{e}$

Caussy D (2006) A field guide: detection, management and surveillance of arsenicosis in South-East Asia Region. WHO Regional Office for South-East Asia, New Delhi

Chang LW, Clarkson TW, Magos L, Suzuki T (1996) Toxicology of metals. CRC Press, Boca Raton

Chang RS, William Leung CY, Cheung TT, Chan CK (2018) Arsenicinduced neuropathy by improper use of Chinese medicine: a case report. Am J Ther 25(3):e392-e393. https://doi.org/10.1097/ MJT.0000000000000576

Chasapis CT, Loutsidou AC, Spiliopoulou CA, Stefanidou ME (2012) Zinc and human health: an update. Arch Toxicol 86(4):521-534. https://doi.org/10.1007/s00204-011-0775-1

Chen SJ, Zhou GB, Zhang XW, Mao JH, de The H, Chen Z (2011) From an old remedy to a magic bullet: molecular mechanisms underlying the therapeutic effects of arsenic in fighting leukemia. Blood 117(24):6425-6437. https://doi.org/10.1182/blood -2010-11-283598

Cherrak SA, Mokhtari-Soulimane N, Berroukeche F et al (2016) In vitro antioxidant versus metal ion chelating properties of flavonoids: a structure-activity investigation. PLoS One 11(10):e0165575. https://doi.org/10.1371/journal.pone.0165575

Chervona Y, Hall MN, Arita A et al (2012) Associations between arsenic exposure and global posttranslational histone modifications among adults in Bangladesh. Cancer Epidemiol Biomark Prev 21(12):2252-2260. https://doi.org/10.1158/1055-9965. epi-12-0833

Chirumbolo S, Bjørklund G, Lysiuk R, Vella A, Lenchyk L, Upyr T (2018) Targeting cancer with phytochemicals via their fine tuning of the cell survival signaling pathways. Int J Mol Sci 19(11):3568

Concha G, Vogler G, Lezcano D, Nermell B, Vahter M (1998) Exposure to inorganic arsenic metabolites during early human development. Toxicol Sci 44(2):185-190. https://doi.org/10.1006/ toxs. 1998.2486

Cooper K, Noller B, Connell D et al (2007) Public health risks from heavy metals and metalloids present in traditional Chinese medicines. J Toxicol Environ Health Part A 70(19):1694-1699. https ://doi.org/10.1080/15287390701434885

Costagliola P, Benvenuti M, Chiarantini L et al (2008) Impact of ancient metal smelting on arsenic pollution in the Pecora River Valley, Southern Tuscany, Italy. Appl Geochem 23(5):12411259. https://doi.org/10.1016/j.apgeochem.2008.01.005
Crisponi G, Nurchi VM, Lachowicz JI, Crespo-Alonso M, Zoroddu MA, Peana M (2015) Kill or cure: misuse of chelation therapy for human diseases. Coord Chem Rev 284:278-285. https://doi. org/10.1016/j.ccr.2014.04.023

Czub M, Kotwicki L, Lang T et al (2018) Deep sea habitats in the chemical warfare dumping areas of the Baltic Sea. Sci Total Environ 616-617:1485-1497. https://doi.org/10.1016/j.scito tenv.2017.10.165

Dart RC, Hurlbut KM, Maiorino RM, Mayersohn M, Aposhian HV, Hassen LV (1994) Pharmacokinetics of meso-2,3-dimercaptosuccinic acid in patients with lead poisoning and in healthy adults. J Pediatr 125(2):309-316. https://doi.org/10.1016/s0022 -3476(94)70217-9

Das J, Ghosh J, Manna P, Sinha M, Sil PC (2009) Arsenic-induced oxidative cerebral disorders: protection by taurine. Drug Chem Toxicol 32(2):93-102. https://doi.org/10.1080/01480540802564171

Dennis JM, Witting PK (2017) Protective role for antioxidants in acute kidney disease. Nutrients. https://doi.org/10.3390/nu9070718

Dyadchenko VV, Petrukhin SY, Novikov OI (2018) Chemical weapon, vol 1 [in Ukrainian]. IE Brovin O.V., Kharkiv

Edwards M, Bełdowski J (2016) Chemical munitions dumped at sea. Deep Sea Res Part II 128:1-3. https://doi.org/10.1016/j. dsr2.2016.04.008

Ernst E (2002) A systematic review of systematic reviews of homeopathy. Br J Clin Pharmacol 54(6):577-582. https://doi.org/10.104 6/j.1365-2125.2002.01699.x

Fajzulina DL, Atamanjuk ED (2007) Toxic polyneuropathy in poisoning with arsenic [in Russian]. Sibirskiy meditsinskiy zhurnal 5:95-98

Fang YZ, Yang S, Wu G (2002) Free radicals, antioxidants, and nutrition. Nutrition 18(10):872-879. https://doi.org/10.1016/s0899 -9007(02)00916-4

Ferreccio C, Yuan Y, Calle J et al (2013) Arsenic, tobacco smoke, and occupation: associations of multiple agents with lung and bladder cancer. Epidemiology 24(6):898-905. https://doi.org/10.1097/ EDE.0b013e31829e3e03

Flora SJ, Bhadauria S, Kannan GM, Singh N (2007) Arsenic induced oxidative stress and the role of antioxidant supplementation during chelation: a review. J Environ Biol 28(2 Suppl):333-347

Flora SJ, Pachauri V (2010) Chelation in metal intoxication. Int J Environ Res Public Health 7(7):2745-2788. https://doi.org/10.3390/ ijerph7072745

Fowler BA, Selene CH, Chou RJ, Jones DL, Sullivan W Jr, Chen CJ (2015) Chapter 28 - arsenic. In: Nordberg GF, Fowler BA, Nordberg M (eds) Handbook on the toxicology of metals, 4th edn. Academic Press, San Diego, pp 581-624

Friedman M (1977) Chemical basis for pharmacological and therapeutic actions of penicillamine. Adv Exp Med Biol 86B:649-673. https://doi.org/10.1007/978-1-4757-9113-6_36

Gao Y, Qian H, Wang H, Chen J, Ren W, Yang F (2019) Assessment of background levels and pollution sources for arsenic and fluoride in the phreatic and confined groundwater of Xi' an city, Shaanxi, China. Environ Sci Pollut Res Int. https://doi.org/10.1007/s1135 6-019-06791-7

Garcia-Sanchez A, Alonso-Rojo P, Santos-Frances F (2010) Distribution and mobility of arsenic in soils of a mining area (Western Spain). Sci Total Environ 408(19):4194-4201. https://doi. org/10.1016/j.scitotenv.2010.05.032

Garelick H, Jones H, Dybowska A, Valsami-Jones E (2008) Arsenic pollution sources. Rev Environ Contam Toxicol 197:17-60. https ://doi.org/10.1007/978-0-387-79284-2_2

Gerhardsson L, Aaseth J (2016) Chapter 7: guidance for clinical treatment of metal poisonings-use and misuse of chelating agents. In: Aaseth J, Crisponi G, Andersen O (eds) Chelation therapy in the treatment of metal intoxication. Academic Press, Boston, pp 313-341 
Gerhardsson L, Kazantzis G (2015) Chapter 23-diagnosis and treatment of metal poisoning: general aspects. In: Nordberg GF, Fowler BA, Nordberg M (eds) Handbook on the toxicology of metals, 4th edn. Academic Press, San Diego, pp 487-505

Ghabaee DNZ, Amiri FT, Moghaddam AE, Khalatbary AR, Zargari M (2017) Administration of zinc against arsenic-induced nephrotoxicity during gestation and lactation in rat model. J Nephropathol 6(2):74

Ghani S, Khan N, Koriyama C, Akiba S, Yamamoto M (2014) $\mathrm{N}$-Acetyl-L-cysteine reduces arsenite-induced cytotoxicity through chelation in U937 monocytes and macrophages. Mol Med Rep 10(6):2961-2966

Goldman M, Dacre JC (1989) Lewisite: its chemistry, toxicology, and biological effects. Rev Environ Contam Toxicol 110:75-115. https://doi.org/10.1007/978-1-4684-7092-5_2

Guha Mazumder DN, De BK, Santra A et al (2001) Randomized placebo-controlled trial of 2, 3-dimercapto-1-propanesulfonate (DMPS) in therapy of chronic arsenicosis due to drinking arsenic-contaminated water. J Toxicol Clin Toxicol 39(7):665-674

Guha Mazumder DN, Ghoshal UC, Saha J et al (1998) Randomized placebo-controlled trial of 2,3-dimercaptosuccinic acid in therapy of chronic arsenicosis due to drinking arsenic-contaminated subsoil water. J Toxicol Clin Toxicol 36(7):683-690. https://doi. org/10.3109/15563659809162616

Hall AH (2002) Chronic arsenic poisoning. Toxicol Lett 128(1-3):6972. https://doi.org/10.1016/s0378-4274(01)00534-3

Han FX, Su Y, Monts DL, Plodinec MJ, Banin A, Triplett GE (2003) Assessment of global industrial-age anthropogenic arsenic contamination. Naturwissenschaften 90(9):395-401. https://doi. org/10.1007/s00114-003-0451-2

Hassan MM (2018) Arsenic in groundwater: poisoning and risk assessment. CRC Press, Baco Raton

Hilmy AM, El-Domiaty NA, Kamal MA, Mohamed MA, Samra WEA (1991) Effect of some arsenic antagonists on the toxicity, distribution and excretion of arsenite and arsenate in rats. Comp Biochem Physiol Part C Comp Pharmacol 99(3):357-362. https ://doi.org/10.1016/0742-8413(91)90256-S

Ho D, Lowenstein EJ (2016) Fowler's solution and the evolution of the use of arsenic in modern medicine. Skinmed 14(4):287-289

Hoenig SL (2007) Compendium of chemical warfare agents. Springer, Berlin

Hsiao CY, Gresham C, Marshall MR (2019) Treatment of lead and arsenic poisoning in anuric patients-a case report and narrative review of the literature. BMC Nephrol 20(1):374. https://doi. org/10.1186/s12882-019-1561-1

Hsin IL, Chou YH, Hung WL, Ko JL, Wang PH (2019) The application of arsenic trioxide in ameliorating ABT-737 target therapy on uterine cervical cancer cells through unique pathways in cell death. Cancers (Basel). https://doi.org/10.3390/cancers12010108

Huang W, Zeng YC (2019) A candidate for lung cancer treatment: arsenic trioxide. Clin Transl Oncol 21(9):1115-1126. https://doi. org/10.1007/s12094-019-02054-6

Hughes MF (2002) Arsenic toxicity and potential mechanisms of action. Toxicol Lett 133(1):1-16. https://doi.org/10.1016/s0378 $-4274(02) 00084-x$

Hughes MF, Beck BD, Chen Y, Lewis AS, Thomas DJ (2011) Arsenic exposure and toxicology: a historical perspective. Toxicol Sci 123(2):305-332. https://doi.org/10.1093/toxsci/kfr184

Iland HJ, Seymour JF (2013) Role of arsenic trioxide in acute promyelocytic leukemia. Curr Treat Options Oncol 14(2):170-184. https ://doi.org/10.1007/s11864-012-0223-3

Jolliffe DM (1993) A history of the use of arsenicals in man. J R Soc Med 86(5):287-289

Jomova K, Jenisova Z, Feszterova M et al (2011) Arsenic: toxicity, oxidative stress and human disease. J Appl Toxicol 31(2):95-107. https://doi.org/10.1002/jat.1649
Jones MM (1995) Chemistry of chelation: chelating agent antagonists for toxic metals. In: Goyer RA, Cherian MG (eds) Toxicology of metals: biochemical aspects. Springer, Berlin, pp 279-304

Kalia K, Flora SJ (2005) Strategies for safe and effective therapeutic measures for chronic arsenic and lead poisoning. J Occup Health 47(1):1-21. https://doi.org/10.1539/joh.47.1

Kannan GM, Flora SJ (2006) Combined administration of $\mathrm{N}$-acetylcysteine and monoisoamyl DMSA on tissue oxidative stress during arsenic chelation therapy. Biol Trace Elem Res 110(1):43-59. https://doi.org/10.1385/BTER:110:1:43

Kazantzis G (2007) CHAPTER 15: diagnosis and treatment of metal poisoning — general aspects. In: Nordberg GF, Fowler BA, Nordberg M, Friberg LT (eds) Handbook on the toxicology of metals, 3rd edn. Academic Press, Burlington, pp 303-317

Keil DE, Berger-Ritchie J, McMillin GA (2011) Testing for toxic elements: a focus on arsenic, cadmium, lead, and mercury. Lab Med 42(12):735-742. https://doi.org/10.1309/lmykgu05bepe7iaw

Kim JJ, Kim YS, Kumar V (2019) Heavy metal toxicity: an update of chelating therapeutic strategies. J Trace Elem Med Biol 54:226231. https://doi.org/10.1016/j.jtemb.2019.05.003

Kim SY, Moon A (2012) Drug-induced nephrotoxicity and its biomarkers. Biomol Ther (Seoul) 20(3):268-272. https://doi.org/10.4062/ biomolther.2012.20.3.268

Konieczynski P, Viapiana A, Lysiuk R, Wesolowski M (2018) Chemical composition of selected commercial herbal remedies in relation to geographical origin and inter-species diversity. Biol Trace Elem Res 182(1):169-177. https://doi.org/10.1007/s1201 1-017-1078-z

Korkina LG, Afanas'ev IB (1997) Antioxidant and chelating properties of flavonoids. Adv Pharmacol 38:151-163. https://doi. org/10.1016/s1054-3589(08)60983-7

Kosnett MJ (2004) Unithiol (DMPS). In: Olson KR (ed) Poisoning and drug overdose, 4 th edn. Lange Medical Books/McGraw-Hill, New York

Kosnett MJ (2013) The role of chelation in the treatment of arsenic and mercury poisoning. J Med Toxicol 9(4):347-354. https:// doi.org/10.1007/s13181-013-0344-5

Kreppel H, Reichl FX, Forth W, Fichtl B (1989) Lack of effectiveness of D-penicillamine in experimental arsenic poisoning. Vet Hum Toxicol 31(1):1-5

Kushwaha P, Yadav A, Samim M, Flora SJS (2018) Combinatorial drug delivery strategy employing nano-curcumin and nanoMiADMSA for the treatment of arsenic intoxication in mouse. Chem Biol Interact 286:78-87. https://doi.org/10.1016/j. cbi.2018.03.006

Karp VK, Danova IV (1997) Unitiol-antidote of toxic metals [In Ukrainian]. Liky 6:60-64

Lachowicz JI, Nurchi VM, Crisponi G et al (2018) para-Aminosalicylic acid in the treatment of manganese toxicity. Complexation of $\mathrm{Mn}^{2+}$ with 4-amino-2-hydroxybenzoic acid and its $\mathrm{N}$-acetylated metabolite. New J Chem 42(10):8035-8049. https://doi. org/10.1039/c7nj04648k

Lachowicz JI, Nurchi VM, Crisponi G et al (2015) Zinc(II) and copper(II) complexes with hydroxypyrone iron chelators. J Inorg Biochem 151:94-106. https://doi.org/10.1016/j.jinor gbio.2015.08.011

Lai MW, Boyer EW, Kleinman ME, Rodig NM, Ewald MB (2005) Acute arsenic poisoning in two siblings. Pediatrics 116(1):249 257. https://doi.org/10.1542/peds.2004-1957

Li C, Srivastava RK, Athar M (2016) Biological and environmental hazards associated with exposure to chemical warfare agents: arsenicals. Ann N Y Acad Sci 1378(1):143-157. https://doi. org/10.1111/nyas.13214

Lian Y, Wang X, Guo P et al (2019) Erythrocyte membrane-coated arsenic trioxide-loaded sodium alginate nanoparticles for 
tumor therapy. Pharmaceutics. https://doi.org/10.3390/pharm aceutics 12010021

Liu JX, Zhou GB, Chen SJ, Chen Z (2012) Arsenic compounds: revived ancient remedies in the fight against human malignancies. Curr Opin Chem Biol 16(1-2):92-98. https://doi. org/10.1016/j.cbpa.2012.01.015

Liu R, Li X, Huang N, Fan M, Sun R (2020) Toxicity of traditional Chinese medicine herbal and mineral products. Adv Pharmacol 87:301-346. https://doi.org/10.1016/bs.apha.2019.08.001

Lubos E, Loscalzo J, Handy DE (2011) Glutathione peroxidase-1 in health and disease: from molecular mechanisms to therapeutic opportunities. Antioxid Redox Signal 15(7):1957-1997. https ://doi.org/10.1089/ars.2010.3586

Maiorino RM, Bruce DC, Aposhian HV (1989) Determination and metabolism of dithiol chelating agents. VI. Isolation and identification of the mixed disulfides of meso-2,3-dimercaptosuccinic acid with L-cysteine in human urine. Toxicol Appl Pharmacol 97(2):338-349. https://doi.org/10.1016/0041008x(89)90338-4

Maiorino RM, Xu ZF, Aposhian HV (1996) Determination and metabolism of dithiol chelating agents. XVII. In humans, sodium 2,3-dimercapto-1-propanesulfonate is bound to plasma albumin via mixed disulfide formation and is found in the urine as cyclic polymeric disulfides. J Pharmacol Exp Ther 277(1):375

Makedonski L, Peycheva K, Stancheva M (2017) Determination of heavy metals in selected black sea fish species. Food Control 72:313-318. https://doi.org/10.1016/j.foodcont.2015.08.024

Mallick P, Mallick JC, Guha B, Khuda-Bukhsh AR (2003) Ameliorating effect of microdoses of a potentized homeopathic drug, Arsenicum Album, on arsenic-induced toxicity in mice. BMC Complement Altern Med 3:7. https://doi. org/10.1186/1472-6882-3-7

Mandal BK, Suzuki KT (2002) Arsenic round the world: a review. Talanta 58(1):201-235. https://doi.org/10.1016/S0039 -9140(02)00268-0

Manna P, Sinha M, Sil PC (2008) Arsenic-induced oxidative myocardial injury: protective role of arjunolic acid. Arch Toxicol 82(3):137-149. https://doi.org/10.1007/s00204-007-0272-8

Martin DS, Willis SE, Cline DM (1990) N-acetylcysteine in the treatment of human arsenic poisoning. J Am Board Fam Pract 3(4):293-296

Masuda H (2018) Arsenic cycling in the Earth's crust and hydrosphere: interaction between naturally occurring arsenic and human activities. Prog Earth Planet Sci 5(1):68. https://doi.org/10.1186/ s40645-018-0224-3

Mathieu D, Mathieu-Nolf M, Germain-Alonso M, Neviere R, Furon D, Wattel F (1992) Massive arsenic poisoning-effect of hemodialysis and dimercaprol on arsenic kinetics. Intensive Care Med 18(1):47-50. https://doi.org/10.1007/bf01706427

McCarty KM, Hanh HT, Kim KW (2011) Arsenic geochemistry and human health in South East Asia. Rev Environ Health 26(1):7178. https://doi.org/10.1515/reveh.2011.010

Medici S, Peana M, Nurchi VM, Lachowicz JI, Crisponi G, Zoroddu MA (2015) Noble metals in medicine: latest advances. Coord Chem Rev 284:329-350. https://doi.org/10.1016/j. ccr.2014.08.002

Mehrandish R, Rahimian A, Shahriary A (2019) Heavy metals detoxification: a review of herbal compounds for chelation therapy in heavy metals toxicity. J Herbmed Pharmacol 8(2):69-77. https ://doi.org/10.15171/jhp.2019.12

Mershiba SD, Dassprakash MV, Saraswathy SD (2013) Protective effect of naringenin on hepatic and renal dysfunction and oxidative stress in arsenic intoxicated rats. Mol Biol Rep 40(5):36813691. https://doi.org/10.1007/s11033-012-2444-8

Milton AH, Hussain S, Akter S, Rahman M, Mouly TA, Mitchell K (2017) A review of the effects of chronic arsenic exposure on adverse pregnancy outcomes. Int J Environ Res Public Health. https://doi.org/10.3390/ijerph14060556

Miodragović Đ, Swindell EP, Sattar Waxali Z, Bogachkov A, O'Halloran TV (2019) Beyond cisplatin: combination therapy with arsenic trioxide. Inorg Chim Acta 496:119030. https://doi. org/10.1016/j.ica.2019.119030

Mishra D, Mehta A, Flora SJ (2008) Reversal of arsenic-induced hepatic apoptosis with combined administration of DMSA and its analogues in guinea pigs: role of glutathione and linked enzymes. Chem Res Toxicol 21(2):400-407. https://doi.org/10.1021/tx700 $315 \mathrm{a}$

Mittal M, Chatterjee S, Flora SJS (2018) Combination therapy with vitamin $\mathrm{C}$ and DMSA for arsenic-fluoride co-exposure in rats. Metallomics 10(9):1291-1306. https://doi.org/10.1039/c8mt0 $0192 \mathrm{~h}$

Modi M, Flora SJ (2007) Combined administration of iron and monoisoamyl-DMSA in the treatment of chronic arsenic intoxication in mice. Cell Biol Toxicol 23(6):429-443. https://doi. org/10.1007/s10565-007-9005-2

Nachman KE, Baron PA, Raber G, Francesconi KA, Navas-Acien A, Love DC (2013) Roxarsone, inorganic arsenic, and other arsenic species in chicken: a US-based market basket sample. Environ Health Perspect 121(7):818-824. https://doi.org/10.1289/ ehp. 1206245

Nachman KE, Love DC, Baron PA et al (2017) Nitarsone, inorganic arsenic, and other arsenic species in Turkey meat: exposure and risk assessment based on a 2014 US market basket sample. Environ Health Perspect 125(3):363-369. https://doi.org/10.1289/ EHP225

Naujokas MF, Anderson B, Ahsan H et al (2013) The broad scope of health effects from chronic arsenic exposure: update on a worldwide public health problem. Environ Health Perspect 121(3):295-302. https://doi.org/10.1289/ehp.1205875

NIOSH (2011) The emergency response safety and health database: blister agent: LEWISITE (L). Centers for Disease Control and Prevention, The National Institute for Occupational Safety and Health

Nurchi VM, Cappai R, Chand K et al (2019) New strong extrafunctionalizable tris(3,4-HP) and bis(3,4-HP) metal sequestering agents: synthesis, solution and in vivo metal chelation. Dalton Trans 48(43):16167-16183. https://doi.org/10.1039/c9dt02905b

Nurchi VM, Crisponi G, Lachowicz JI, Medici S, Peana M, Zoroddu MA (2016) Chemical features of in use and in progress chelators for iron overload. J Trace Elem Med Biol 38:10-18. https://doi. org/10.1016/j.jtemb.2016.05.010

Nurchi VM, Djordjevic AB, Crisponi G, Alexander J, Bjørklund G, Aaseth J (2020) Arsenic toxicity: molecular targets and therapeutic agents. Biomolecules. https://doi.org/10.3390/biom10020235

Oberoi S, Barchowsky A, Wu F (2014) The global burden of disease for skin, lung, and bladder cancer caused by arsenic in food. Cancer Epidemiol Biomark Prev 23(7):1187-1194. https://doi. org/10.1158/1055-9965.EPI-13-1317

OPCW (1992) Convention on the prohibition of the development, production, stockpiling and use of chemical weapons and on their destruction (CWC). OPCW, Geneva

Oremland RS, Stolz JF (2003) The ecology of arsenic. Science 300(5621):939-944. https://doi.org/10.1126/science.1081903

Oyagbemi AA, Omobowale TO, Ola-Davies OE et al (2018) Protective effect of Azadirachta indica and vitamin $\mathrm{E}$ against arsenic acid-induced genotoxicity and apoptosis in rats. J Diet Suppl 15(3):251-268. https://doi.org/10.1080/19390211.2017.1336147

Pachauri V, Mehta A, Mishra D, Flora SJ (2013) Arsenic induced neuronal apoptosis in guinea pigs is $\mathrm{Ca}^{2+}$ dependent and abrogated by chelation therapy: role of voltage gated calcium channels. Neurotoxicology 35:137-145. https://doi.org/10.1016/j.neuro .2013 .01 .006 
Peana M, Medici S, Nurchi VM, Crisponi G, Zoroddu MA (2013) Nickel binding sites in histone proteins: spectroscopic and structural characterization. Coord Chem Rev 257(19):2737-2751. https://doi.org/10.1016/j.ccr.2013.02.022

Pfaff AR, Beltz J, King E, Ercal N (2019) Medicinal thiols: current status and new perspectives. Mini Rev Med Chem. https://doi. org/10.2174/1389557519666191119144100

Pinto B, Goyal P, Flora SJ, Gill KD, Singh S (2014) Chronic arsenic poisoning following ayurvedic medication. J Med Toxicol 10(4):395-398. https://doi.org/10.1007/s13181-014-0389-0

Pinto SS, McGill CM (1953) Arsenic trioxide exposure in industry. Ind Med Surg 22(7):281-287

Prokhach EY, Mykhalska LL (2009) Ways to improve the effectiveness of environmental monitoring aimed at preventing emergencies related to the presence of ammunition in the sea during the Great Patriotic War [in Ukrainian]. Probl Emerg Collect Sci Works 9:88-94

Quansah R, Armah FA, Essumang DK et al (2015) Association of arsenic with adverse pregnancy outcomes/infant mortality: a systematic review and meta-analysis. Environ Health Perspect 123(5):412-421. https://doi.org/10.1289/ehp.1307894

Rahman MM, Hossain KFB, Banik S et al (2019) Selenium and zinc protections against metal-(loids)-induced toxicity and disease manifestations: a review. Ecotoxicol Environ Saf 168:146-163. https://doi.org/10.1016/j.ecoenv.2018.10.054

Rahman MM, Uson-Lopez RA, Sikder MT et al (2018) Ameliorative effects of selenium on arsenic-induced cytotoxicity in PC12 cells via modulating autophagy/apoptosis. Chemosphere 196:453466. https://doi.org/10.1016/j.chemosphere.2017.12.149

Ratnaike RN (2003) Acute and chronic arsenic toxicity. Postgrad Med J 79(933):391-396. https://doi.org/10.1136/pmj.79.933.391

Ravenscroft P, Brammer H, Richards K (2011) Arsenic pollution: a global synthesis, vol 94. Wiley, New York

Rossignol DA (2019) The use of N-acetylcysteine as a chelator for metal toxicity the therapeutic use of $\mathrm{N}$-acetylcysteine (NAC) in medicine. Springer, Berlin, pp 169-179

Roy A, Das A, Das R, Haldar S, Bhattacharya S, Haldar PK (2014) Naringenin, a citrus flavonoid, ameliorates arsenic-induced toxicity in Swiss albino mice. J Environ Pathol Toxicol Oncol 33(3):195-204. https://doi.org/10.1615/jenvironpatholtoxico loncol.2014010317

Roy P, Dey U, Chattoraj S, Mukhopadhyay D, Mondal NK (2017) Modeling of the adsorptive removal of arsenic(III) using plant biomass: a bioremedial approach. Appl Water Sci 7(3):13071321. https://doi.org/10.1007/s13201-015-0339-2

Rubino FM (2015) Toxicity of glutathione-binding metals: a review of targets and mechanisms. Toxics 3(1):20-62. https://doi. org $/ 10.3390 /$ toxics 3010020

Sah S, Vandenberg A, Smits J (2013) Treating chronic arsenic toxicity with high selenium lentil diets. Toxicol Appl Pharmacol 272(1):256-262. https://doi.org/10.1016/j.taap.2013.06.008

Saha JC, Dikshit AK, Bandyopadhyay M, Saha KC (1999) A review of arsenic poisoning and its effects on human health. Crit Rev Environ Sci Technol 29(3):281-313. https://doi.org/10.1080/10643 389991259227

Saha KC (1995) Chronic arsenical dermatoses from tube-well water in West Bengal during 1983-87. Indian J Dermatol 40(1):1-12

Samar V (2013)Chemical threat from the sediments of the sea [in Russian] Mirror of the Week. ZN UA

Sanchez TR, Perzanowski M, Graziano JH (2016) Inorganic arsenic and respiratory health, from early life exposure to sex-specific effects: a systematic review. Environ Res 147:537-555. https:// doi.org/10.1016/j.envres.2016.02.009

Sarkozi K, Papp A, Mate Z, Horvath E, Paulik E, Szabo A (2015) Rutin, a flavonoid phytochemical, ameliorates certain behavioral and electrophysiological alterations and general toxicity of oral arsenic in rats. Acta Biol Hung 66(1):14-26. https://doi. org/10.1556/ABiol.66.2015.1.2

Sayed AH, Kitamura D, Oda S, Kashiwada S, Mitani H (2019) Cytotoxic and genotoxic effects of arsenic on erythrocytes of Oryzias latipes: bioremediation using Spirulina platensis. J Trace Elem Med Biol 55:82-88. https://doi.org/10.1016/j.jtemb.2019.06.007

Schardein JL, Macina OT (2006) Human developmental toxicants: aspects of toxicology and chemistry. CRC Press, Cambridge

Schenk VW, Stolk PJ (1967) Psychosis following arsenic (possibly thallium) poisoning. A clinical-neuropathological report. Psychiatr Neurol Neurochir 70(1):31-37

Schubert J, Derr SK (1978) Mixed ligand chelate therapy for plutonium and cadmium poisoning. Nature 275(5678):311-313. https://doi. org/10.1038/275311a0

Schutzmeier P, Focil Baquerizo A, Castillo-Tandazo W, Focil N, Bose-O'Reilly S (2018) Efficacy of $N, N^{\prime}$-bis-(2-mercaptoethyl) isophthalamide on mercury intoxication: a randomized controlled trial. Environ Health 17(1):15. https://doi.org/10.1186/s 1294 $0-018-0358-1$

Sears ME (2013) Chelation: harnessing and enhancing heavy metal detoxification-a review. Sci World J 2013:219840. https://doi. org/10.1155/2013/219840

Sharma A, Flora SJS (2018) Nutritional management can assist a significant role in alleviation of arsenicosis. J Trace Elem Med Biol 45:11-20. https://doi.org/10.1016/j.jtemb.2017.09.010

Shen S, Li XF, Cullen WR, Weinfeld M, Le XC (2013) Arsenic binding to proteins. Chem Rev 113(10):7769-7792. https://doi. org/10.1021/cr300015c

Shi H, Shi X, Liu KJ (2004) Oxidative mechanism of arsenic toxicity and carcinogenesis. Mol Cell Biochem 255(1-2):67-78. https:// doi.org/10.1023/b:mcbi.0000007262.26044.e8

Smedley PL, Kinniburgh DG (2002) A review of the source, behaviour and distribution of arsenic in natural waters. Appl Geochem 17(5):517-568. https://doi.org/10.1016/S0883-2927(02)00018-5

Spilchuk V, Thompson A (2019) Chronic arsenic poisoning from traditional Chinese medicine. CMAJ 191(15):E424. https://doi. org/10.1503/cmaj.181176

Steinbrenner H, Speckmann B, Klotz LO (2016) Selenoproteins: antioxidant selenoenzymes and beyond. Arch Biochem Biophys 595:113-119. https://doi.org/10.1016/j.abb.2015.06.024

Steinmaus C, Ferreccio C, Acevedo J et al (2014) Increased lung and bladder cancer incidence in adults after in utero and early-life arsenic exposure. Cancer Epidemiol Biomark Prev 23(8):15291538. https://doi.org/10.1158/1055-9965.EPI-14-0059

Straif K, Benbrahim-Tallaa L, Baan R et al (2009) A review of human carcinogens-part C: metals, arsenic, dusts, and fibres. Lancet Oncol 10(5):453-454. https://doi.org/10.1016/S1470 -2045(09)70134-2

Susan A, Rajendran K, Sathyasivam K, Krishnan UM (2019) An overview of plant-based interventions to ameliorate arsenic toxicity. Biomed Pharmacother 109:838-852. https://doi.org/10.1016/j. biopha.2018.10.099

Szubska M (2018) Arsenic in the environment of the Baltic Sea-A Review. In: Zielinski T, Sagan I, Surosz W (eds) Interdisciplinary approaches for sustainable development goals: economic growth, social inclusion and environmental protection. Springer International Publishing, Cham, pp 111-131

Thakre PK, Golla U, Biswas A, Tomar RS (2020) Identification of Histone $\mathrm{H} 3$ and $\mathrm{H} 4$ amino acid residues important for the regulation of arsenite stress signaling in Saccharomyces cerevisiae. Chem Res Toxicol. https://doi.org/10.1021/acs.chemrestox.9b00471

Thompson DJ (1993) A chemical hypothesis for arsenic methylation in mammals. Chem Biol Interact 88(2-3):14-89. https://doi. org/10.1016/0009-2797(93)90086-e

Upadhyay MK, Shukla A, Yadav P, Srivastava S (2019) A review of arsenic in crops, vegetables, animals and food products. 
Food Chem 276:608-618. https://doi.org/10.1016/j.foodc hem.2018.10.069

USGS (2019) Mineral Commodity Summaries 2019. In: USGS (ed) Mineral Commodity Summaries. US Geological Survey, Reston, p 200

Uthus EO (1992) Evidence for arsenic essentiality. Environ Geochem Health 14(2):55-58. https://doi.org/10.1007/BF01783629

Vahter M (2008) Health effects of early life exposure to arsenic. Basic Clin Pharmacol Toxicol 102(2):204-211. https://doi.org/10.111 1/j.1742-7843.2007.00168.x

Valko M, Rhodes CJ, Moncol J, Izakovic M, Mazur M (2006) Free radicals, metals and antioxidants in oxidative stress-induced cancer. Chem Biol Interact 160(1):1-40. https://doi.org/10.1016/j. cbi.2005.12.009

Vasken Aposhian H, Carter DE, Hoover TD, Hsu C-A, Maiorino RM, Stine E (1984) DMSA, DMPS, and DMPA — as arsenic antidotes. Toxicol Sci 4(2part2):58-70

Vlasyk LI, Voloshina NA, Georgiants MA (2009) Protocol of care for acute poisoning [in Ukrainian]. Mod Probl Toxicol (section "Antidote therapy", part 2) (3-4):77-113. http://medved.kiev.ua/ web_journals/arhiv/toxicology/2009/2_2009/str81.pdf

Wahiduzzaman M, Ota A, Hosokawa Y (2020) Novel mechanistic insights into the anti-cancer mode of arsenic trioxide. Curr Cancer Drug Targets 20(2):115-129. https://doi.org/10.2174/15680 09619666191021122006

Walshe JM (1956) Wilson's disease; new oral therapy. Lancet 270(6906):25-26. https://doi.org/10.1016/s0140-6736(56)91859 $-1$

Wang S, Mulligan CN (2006) Occurrence of arsenic contamination in Canada: sources, behavior and distribution. Sci Total Environ 366(2-3):701-721. https://doi.org/10.1016/j.scito tenv.2005.09.005

Wang X, Hu Y, Mo J et al (2019) Arsenene: a potential therapeutic agent for acute promyelocytic leukaemia cells by acting on nuclear proteins. Angew Chem Int Ed Engl. https://doi. org/10.1002/anie.201913675

Wexler P (2000) Information resources in toxicology. Elsevier, New York

WHO (2001) Environmental health criteria 224: arsenic and arsenic compounds. World Health Organization, Geneva, pp 1-108

WHO (2004) Guidelines for drinking-water quality, vol 1. World Health Organization, Geneva, p 515

Wu HE, Abdel-Gawad NM, Gharbaoui Y, Teixeira AL, Pigott TA (2017) An unusual case of acute psychosis with obsessive-compulsive features following arsenic poisoning. J Psychiatr Pract 23(5):382-385. https://doi.org/10.1097/PRA.0000000000000254

Wu ML, Deng JF, Lin KP, Tsai WJ (2013) Lead, mercury, and arsenic poisoning due to topical use of traditional Chinese medicines. Am J Med 126(5):451-454. https://doi.org/10.1016/j.amjme d.2013.01.001

Wu Q, Chen X, Wang P et al (2020) Delivery of arsenic trioxide by multifunction nanoparticles to improve the treatment of hepatocellular carcinoma. ACS Appl Mater Interfaces 12(7):80168029. https://doi.org/10.1021/acsami.9b22802
Yadav A, Flora SJ (2016) Nano drug delivery systems: a new paradigm for treating metal toxicity. Expert Opin Drug Deliv 13(6):831841. https://doi.org/10.1517/17425247.2016.1160890

Yadav A, Lomash V, Samim M, Flora SJ (2012) Curcumin encapsulated in chitosan nanoparticles: a novel strategy for the treatment of arsenic toxicity. Chem Biol Interact 199(1):49-61. https://doi. org/10.1016/j.cbi.2012.05.011

Yang MH, Chang KJ, Li B, Chen WS (2019) Arsenic trioxide suppresses tumor growth through antiangiogenesis via notch signaling blockade in small-cell lung cancer. Biomed Res Int 2019:4647252. https://doi.org/10.1155/2019/4647252

Young JL, Cai L, States JC (2018) Impact of prenatal arsenic exposure on chronic adult diseases. Syst Biol Reprod Med 64(6):469-483. https://doi.org/10.1080/19396368.2018.1480076

Zhang L, Tian W, Kim S, Ding W, Tong Y, Chen S (2015) Arsenic sulfide, the main component of realgar, a traditional Chinese medicine, induces apoptosis of gastric cancer cells in vitro and in vivo. Drug Des Devel Ther 9:79-92. https://doi.org/10.2147/ DDDT.S74379

Zhang X, Cornelis R, de Kimpe J, Mees L, Lameire N (1998) Study of arsenic-protein binding in serum of patients on continuous ambulatory peritoneal dialysis. Clin Chem 44(1):141-147

Zhao D, Wang J, Yin D et al (2020) Arsanilic acid contributes more to total arsenic than roxarsone in chicken meat from Chinese markets. J Hazard Mater 383:121178. https://doi.org/10.1016/j. jhazmat.2019.121178

Zhao H, Wang Y, Yang X et al (2019) Zinc alleviates arsenism in common carp: varied change profiles of cytokines and tight junction proteins among two intestinal segments. Fish Shellfish Immunol 94:761-768. https://doi.org/10.1016/j.fsi.2019.09.069

Zheng J, Zhang K, Liu Y, Wang Y (2019) Fatal acute arsenic poisoning by external use of realgar: case report and 30 years literature retrospective study in China. Forensic Sci Int 300:e24-e30. https ://doi.org/10.1016/j.forsciint.2019.03.012

Zoidis E, Seremelis I, Kontopoulos N, Danezis GP (2018) Seleniumdependent antioxidant enzymes: actions and properties of selenoproteins. Antioxidants (Basel). https://doi.org/10.3390/antio x7050066

Zoroddu MA, Aaseth J, Crisponi G, Medici S, Peana M, Nurchi VM (2019) The essential metals for humans: a brief overview. J Inorg Biochem 195:120-129. https://doi.org/10.1016/j.jinor gbio.2019.03.013

Zoroddu MA, Peana M, Medici S, Casella L, Monzani E, Costa M (2010) Nickel binding to histone H4. Dalton Trans 39(3):787793. https://doi.org/10.1039/b916019c

Publisher's Note Springer Nature remains neutral with regard to jurisdictional claims in published maps and institutional affiliations. 